\title{
Etnografinès medžiagos rinkimo priemonių kalendorinių švenčių tema raidos tendencijos
}

\author{
ASTA VENSKIENE \\ Vytauto Didžiojo universitetas, K. Donelaičio g. 52, LT-44244 Kaunas \\ El. paštas: a.venskiene@hmf.vdu.lt
}

\begin{abstract}
Tyrimo objektas - Lietuvoje XX-XXI a. 1-ajame dešimtmetyje sudarytos priemonès (programos, anketos, klausimynai) etnografinei medžiagai apie kalendorines šventes rinkti. Tikslas - atlikti išspausdintų etnografinès medžiagos rinkimo priemonių apie kalendorines šventes kiekybinès kaitos ir kokybès analizę. Darbe naudojami dokumentų (programų, klausimynų, anketų) analizės, aprašomasis, lyginamasis, interpretacinis metodai. Atlikus etnografinès medžiagos rinkimo priemonių analizę, paaiškèjo, kad pirmosios teminès anketos medžiagai apie kalendorines šventes rinkti buvo išspausdintos XX a. 4-ajame dešimtmetyje, nors atskirų klausimų apie kalendorines šventes galima rasti anksčiau išspausdintose etnografinès medžiagos rinkimo priemonèse. Sovietmečiu etnografinių medžiagos rinkimo priemonių apie kalendorines šventes buvo mažai. Pirmoji šia tema publikuota priemone pasirodé 1982 m. Daugiausia klausimynų, anketų, skirtų etnografinei medžiagai apie kalendorines šventes rinkti, sudaryta Atgimimo ir nepriklausomos Lietuvos laikotarpiu - 1989-2007 m.
\end{abstract}

Raktažodžiai: kalendorinès šventès, etnografinès medžiagos rinkimo priemonès, programos, klausimynai, anketos

Vienas pagrindinių etnologinių tyrimų šaltinių yra duomenys, surinkti lauko tyrimų metu. Juos atliekant dažniausiai vadovaujamasi iš anksto paruoštomis medžiagos rinkimo priemonėmis (klausimynais, anketomis ir pan.), kurių sudarymas priklauso nuo duomenų rinkimo (tyrimo) tikslų, metodinių autoriaus nuostatų. Etnografinès medžiagos rinkimo priemonèje suformuluoti klausimai lemia surinktos medžiagos pobūdį. Etnografų, etnologų, antropologų ir kitų sričių tyrëjų darbe plačiai naudojami klausimynai. Anot Victoro C. de Muncko, klausimynai yra dažniausiai socialiniuose moksluose naudojamas metodas renkant informaciją iš žmonių apie juos pačius. Svarbiausia klausimynų efektyvumo ir populiarumo priežastimi laikoma tai, kad visi informantai turi atsakyti ị lygiai tokius pat klausimus, todèl galima manyti, kad jų atsakymų variacijos atspindi individų ar grupių tikejjimų, pažiūrų, vertybių bei kitokius skirtumus $[7,116]$. Vadovaujantis tinkamai sudarytais klausimynais, surinktus ir apdorotus duomenis galima palyginti [2,251], todèl jie laikomi patikimu duomenų rinkimo metodu. Anot J. Mardosos, Lietuvoje dauguma priemonių, skirtų medžiagai rinkti, buvo klausimynai, naudoti interviu būdu apklausiant medžiagos pateikejus, todèl absoliuti dauguma duomenų sukaupta naudojantis būtent šiuo metodu 
[26, 36]. Žinoma, etnografinè medžiaga buvo renkama pasitelkus ir kitus metodus, tačiau laikantis anksčiau išdėstytos pozicijos, kad dauguma duomenų surinkta naudojant klausimynus, manyčiau, yra prasminga atlikti jų analizę, nes klausimynų tam tikromis temomis buvimas ar nebuvimas, jų gausa iš dalies atspindi ir etnografinès medžiagos rinkimo, tyrimų tendencijas.

Klausimynai, kaip priemonè etnografinei medžiagai rinkti, Lietuvoje naudoti nuo XIX a. pradžios (1) ir, anot A. Čepaitienès, yra nusistovèjusi metodologinè taisyklè $[5,43]$. Tačiau Lietuvoje etnografinès medžiagos rinkimo priemonès vadintos įvairiai ir pavadinimas ne būtinai buvo susijęs su jų sudarymo metodika. Kaip pastebejjo J. Mardosa, dažnai bet koks klausimų rinkinys vadinamas anketa. Klausimynai ir anketos buvo sudaromi labai panašiai arba jų sudarymo metodika buvo visiškai tokia pati, skirtingi buvo tik duomenų rinkimo būdai [26, 7]. Straipsnyje nesigilinsime ị medžiagos rinkimo priemonès pavadinimo ir jos struktūros atitiktis, metodikos specifiką, naudosime toki pavadinimą, koks pateikiamas analizuojamame leidinyje. Pažymėtina, kad po Antrojo pasaulinio karo iki XX a. 10-ojo dešimtmečio medžiagos rinkimo priemonès leidiniuose dažniausiai vadintos anketomis.

Kadangi yra sudaryta daug ịvairios tematikos medžiagos rinkimo priemonių ir visas jas viename straipsnyje būtų sudètinga aptarti, autore analizei pasirinko tik skirtas etnografinei medžiagai apie kalendorines šventes rinkti. Taigi, šio tyrimo objektas - Lietuvoje XX-XXI a. 1-ajame dešimtmetyje sudarytos priemonès (programos, anketos, klausimynai) etnografinei medžiagai apie kalendorines šventes rinkti. Analizei naudotos tik publikuotos priemonès (2). Daugiausia demesio bus skiriama XX a. II pusèje - XXI a. pradžioje išleistų priemonių analizei, tačiau aptarsiu ir XX a. I pusejje išleistas programas, kurios parodo to laikmečio sampratą apie duomenų rinkimą. Žinoma, daugelis jų savo struktūra, iš dalies tikslais, skiriasi nuo XX a. II pusès teminių klausimynų. Programų struktūra būna ne vientisa. Jose persipina medžiagos rinkimo nurodymai, temos ir trumpi konkretūs teiginiai, kurie gali būti formuluojami ir kaip klausimai pateikejjams, pavyzdžiui, „Bičių kuopimas (Bičiuliai). Kaip ir kuo smilkoma, kame ugnis užgeso. Kokios formos koriai ir ką reiškia“ $[13,415]$. Tokias programas reiktų laikyti ne tik tyrimų gairèmis, bet ir vadovu medžiagai rinkti, medžiagos rinkimo priemone. Programos ir medžiagos rinkimas, remiantis jomis, manyčiau, iš dalies primena šiandien plačiai naudojamą etnografinių apklausų formą - iš dalies sustruktūrintus interviu, kai duomenų rinkejas turi kelis pagrindinius klausimus, tačiau, priklausomai nuo atsakymų, gali būti nukrypstama ir gilinamasi ì papildomą informaciją $[5,35]$.

Darbo tikslas - atlikti išspausdintų etnografinès medžiagos rinkimo priemonių apie kalendorines šventes kiekybinès kaitos ir kokybės analizę. Uždaviniai - išanalizavus etnografinès medžiagos rinkimo priemonių bibliografinius aprašus, atskirai publikuotus etnografinius klausimynus bei jų rinkinius, nustatyti medžiagos rinkimo priemonių kūrimo tendencijas bei kaip XX-XXI a. 1-ajame dešimtmetyje keitèsi jų skaičius; atkreipti dèmesị $\mathfrak{i}$ klausimynų sudarymo, klausimų formulavimo, pateikimo principus.

Darbe naudojami dokumentų (programų, klausimynų, anketų) analizės, aprašomasis, lyginamasis, interpretacinis metodai.

(1) Klausimynai, kaip duomenų rinkimo priemoné, žinomi nuo XVIII a. pab. Jų atsiradimas siejamas su Johno Howeverio atliktu išsamiu britų kalejjimų tyrimu [2, 251-252].

(2) Autorè neturèjo tikslo suregistruoti visas kalendorinių švenčių tema sudarytas medžiagos rinkimo priemones. Ir vargu ar tai apskritai ¿̨manoma, nes daugelis klausimynų plito rankraštiniais variantais. Jie niekada nebuvo atspausdinti ir tiesiog neišliko. 
Pagrindiniai straipsnio rašymo šaltiniai yra nuo XX a. 5-ojo dešimtmečio V. Miliaus publikuotos etnografinių anketų bibliografinès rodyklès; ịvairios metodinès rekomendacijos kraštotyrininkams, kuriose buvo spausdinamos ir etnografinès medžiagos rinkimo priemonès; Istorijos instituto Etnografijos (nuo 1996 m. Etnologijos) skyriaus tyrèjų sudaryti „Etnografinių klausimynų lapai“; pavieniai atskirų tyrèjų klausimynai ir etnografinių klausimynų rinkiniai.

Klausimynų, anketų etnografinei medžiagai rinkti kūrimo istoriją XIX-XX a. išsamiai išanalizavo J. Mardosa [26, 6-38] (šiame leidinyje taip pat yra ir ịvairių autorių sudarytų etnografinių klausimynų pavyzdžių). Minètas autorius aptarè metodinių ir medžiagos rinkimo priemonių kūrimo ištakas, klausimynų ir anketų sampratas bei metodinius jų skirtumus $[26,7]$.

Etnografinių šaltinių rinkimo programos aptartos Rasos Paukštytės-Šaknienės, Vidos Savoniakaitès, Danguolès Svidinskaitès, Žilvyčio Šaknio, Irmos Šidiškienès straipsnyje „Lietuvos etnologijos šaltinių klasifikacija“. Daugiausia dėmesio skiriama J. Balio sudarytų „Tautosakos rinkejo vadovų“ analizei $[45,46]$. Nors vadovai skirti tautosakinei medžiagai rinkti, tačiau, anot autorių, „tikejjimai - tiek etnologijos, tiek tautosakos objektas“ $[35,15]$, todèl jie reikšmingi ir etnologams. Straipsnyje daugiausia dèmesio skiriama XIX a. pabaigoje - XX a. pradžioje sudarytų medžiagos rinkimo programų santykiui su etnologijos šaltinių klasifikacija atskleisti. Anot autorių, programas „galima laikyti pirmosiomis gimstančios etnologijos ir gretimų mokslų klasifikacijomis“ $[35,15]$.

I. R. Merkienè knygoje „Šiokiadienių ir šventadienių etnografija“ [44, 11-41] pristatė etnografinès medžiagos rinkimo metodiką, aptarè objektų ir pateikèjų atranką bei duomenų fiksavimo būdus, etnografinių klausimynų sudarymo pagrindus. V. Savoniakaitė straipsnyje „Apie Lietuvos etnologijos istoriją“ aptarè ir etnografinès medžiagos rinkimo bei klausimynų sudarymo temą. Anot autorès, sovietmečiu klausimynai buvo sudaromi remiantis pozityvizmo metodologija, kuri „formavo mokslininkų siekį sukaupti pakankamai objektyvių, patikimų duomenų, kad būtų galima kurti, pritaikyti ar patvirtinti mokslines hipotezes ar teorijas“ $[39,62]$. Apie naudotų analizès metodų itaką etnografiniams lauko tyrimams bei klausimų formulavimo pobūdžiui rašoma ir kitame minètos autorès straipsnyje $[40,61-72]$.

Analizuodamas iniciacinius ir kalendorinius jaunimo papročius Mažojoje Lietuvoje ir Žemaitijoje Ž. Šaknys trumpai apžvelgia ir kalendorinių papročių tyrinejjimo istoriją. Autorius akcentuoja programų praktinę naudą renkant etnografinę medžiagą ir teigia, kad Prano Būtèno „Lietuvių tautotyros žinių ir senienų rinkimo programa“ buvo prieinama tik nedidelei medžiagos rinkejų grupei, o daugiau duomenų apie kalendorines šventes surinkta tik naudojantis Jono Balio sudarytais tautosakos rinkejjo vadovais [43, 83-85].

A. Čepaitienė, apibendrindama kitų autorių, rašiusių etnografinès medžiagos rinkimo tema, darbus, iškèlè Lietuvos etnologų požiūrio ị etnografinio aprašo vertę, jo santykio su tikrove klausimus. Svarstoma, ar įmanoma etnografiniame pasakojime atmintị aiškiai atskirti nuo dabarties [5, 39-46].

\section{ETNOGRAFINĖS MEDŽIAGOS APIE KALENDORINES ŠVENTES RINKIMO PRIEMONĖS IKI ANTROJO PASAULINIO KARO}

Kaip jau minèta, XX a. I pusèje sudarytos programos savo struktūra skiriasi nuo teminių klausimynų, tačiau tuo metu jomis vadovaujantis buvo vykdoma etnografinè veikla, renkami etnografiniai duomenys. Tiesa, griežtos skirties tarp mokslo sričių nebuvo - vienoje 
programoje galèjo būti klausimai iš etnografijos, folkloro, kartais archeologijos, gamtos ir kitų sričių. Tiesiog stengtasi surinkti kuo daugiau informacijos apie Lietuvą, jos praeiti.

Nepriklausomos Lietuvos tarp dviejų karų laikotarpiu programos buvo ne tik leidžiamos atskirais leidinèliais, bet ir platinamos spaudoje, kad būtų labiau prieinamos žmonèms. Tikètasi, jog išsilavinusi visuomenès dalis, ypač mokytojai, gimnazistai, studentai, jaunieji ūkininkai, aktyviai ịsijungs ị tautotyros darbą, vadovaudamiesi publikuotais metodiniais nurodymais bei medžiagos rinkimo priemonėmis. Gana daug ịvairių metodinių nurodymų, medžiagos rinkimo priemonių - instrukcijų, patarimų, programu yra paruošęs Ignas Končius [32, 25-26]. Tačiau kalendorinèms šventèms juose skiriama mažai dėmesio. Kaip pavyzdị paanalizuosime I. Končiaus „Programą etnografijos medžiagai rinkti“, paskelbtą laikraštyje „Švietimo darbas“. Anot autoriaus, jis šią programą sudare „Dotnuvos Žemès Ükio Technikumo moksleivių kuopelei „Gimtajam kraštui tirti“ [13, 411-417]. Programa yra gana plati, užima 6 laikraščio puslapius. Temos suskirstytos ị tris stambius skyrius su daugybe vienas kitą papildančių poskyrių. Pirmasis skyrius vadinasi „Medžiaginè kultūra“, kuriame pateikiamos temos apie gyvenamąją sodybą, jos pastatus, ūkí, daržus ir t. t. (21 tema) (3). Antrajame skyriuje „Dvasinè kultūra“ sugrupuotos temos apie folklorą bei liaudies mediciną (47 temos). Trečiasis skyrius pavadintas „Papročiai. Teisè. Socialinis klausimas“ (37 temos). Šio skyriaus pirmajame poskyryje „Papročiai ir apeigos" randame vieną temą, susijusią su kalendorinėmis šventėmis. Autoriaus manymu, reiktų aprašyti „Kalėdų, Užgavènių, Velykų (nuo kalnų važinèjimas, ratas ant ledo; „morë“, supynès), Žolių šventès, Visų Šventų (Vèlių dieną); Kryžiaus dienų, Kūčių“ papročius [13, 415]. Matome, kad dauguma aptartų švenčių yra didžiosios metinès šventès, kurios programos sudarymo laiku (išleista 1923) buvo plačiai švęstos. Po trijų švenčių pavadinimų skliaustuose išvardyti šventiniai elementai, daugiausia būdingi Užgavėnėms. Lieka neaišku, kokiu pagrindu, kodèl autorius atrinko būtent šias septynias kalendorines šventes ir siūlè apie jas rinkti etnografinę medžiagą. Siekiant įtraukti jaunus ūkininkus rinkti etnografinę, tautosakinę medžiagą buvo organizuojami konkursai. Būtent tokiam konkursui I. Končius sudarè „Ūkiškosios tautosakos rinkimo programą“ [14]. Knygelèje pateikti metodiniai nurodymai, kaip rinkti, kur siųsti medžiagą, išdèstomos konkurso sąlygos. Programą sudaro 137 klausimai, du iš jų netiesiogiai susiję su kalendorinèmis šventemis. Šventès čia vaidina pagalbinị vaidmenị siekiant išsiaiškinti sėjos pradžią, ūkininkų laiko sampratą. I. Končiaus sudarytų programų tikslas - patarti, kaip rinkti etnografinę medžiagą, kokiomis temomis, ko klausti žmonių. Kai kurios jo sudarytos programos, pavyzdžiui, jau minèta „Ūkiškosios tautosakos rinkimo programa“ savo struktūra nesiskiria nuo klausimyno. Programų klausimų ar temų pobūdị tikriausiai lèmė nuostata, kad pirmiausia reikia užfiksuoti nykstančias kultūros realijas. Kalendorinių švenčių I. Končius, matyt, nelaikè nykstančiomis, todèl medžiagai apie jas rinkti neskyrè daug dèmesio.

Lenkams tuomet priklausiusiame Vilniaus Stepono Batoro universitete $1924 \mathrm{~m}$. buvo i̊steigtas Etnologijos institutas, kurị sudare Etnologijos katedra ir Etnografijos muziejus [42, 102-103]. Instituto ịkūrejja profesorè C. Baudouin de Courtnenay-Ehrenkreutzowa vadovavosi aprašomąja-stebejjimo metodika ir svarbiausiu instituto tikslu laikè buvusios LDK ir gretimose teritorijose vykdomus tyrinèjimus bei muziejui renkamus artefaktus. Tam tikslui buvo sudaromos lauko tyrimų anketos $[6,100]$. C. Baudouin de Courtnenay-Ehrenkreutzowos lenkų kalba parengtuose nurodymuose [48] šiek tiek dėmesio skiriama ir kalendorinèms

(3) Autorius naudoja labai painią numeraciją (romeniškus ir arabiškus skaičius, didžiąsias ir mažąsias raides), kartais keli klausimai ar teiginiai žymimi vienu numeriu, todèl sunku pasakyti tikslų klausimų skaičių. 
šventèms. Skyriuje apie dvasinę kultūrą išskirtame poskyryje „Bažnytinès, šeimos, žemdirbystès ir kitos apeigos" yra nurodymai rinkti žinias apie Trijų karalių, Apreiškimo Marijai, Šv. Jurgio, Šv. Jono ir kitas šventes [48, 26-27].

Remdamasis lietuvių, latvių, rusų ir kitų šalių patirtimi, plačiausią folkloro ir etnografinès medžiagos rinkimo programą sudarè P. Būtènas. Pratarmèje teigiama, kad „tautotyros žinių ir senienų rinkimo programa" sudaryta siekiant palengvinti etnografų darbą $[25,4]$. Anot S. Skrodenio, „sudarymo ir klausimų apimties požiūriu“ - tai viena geriausių iki tol skelbtų lietuviškų programų [41, 18-19]. P. Būtẻno sudarytoje programoje yra per pustrečio tūkstančio klausimų iš įvairių kultūros sričių [25, 44-53]. Šią programą galime laikyti metodine priemone, kurioje pateikiami nurodymai, kaip reikia rinkti medžiagą bei pridedami teminiai klausimynai, daugelis kurių savo struktūra labai panašūs ị šiuolaikinius, tačiau kartais tarp klausimų ịsiterpia trumpi metodiniai nurodymai. Programą sudaro šešiolika skirtingo dydžio skyrių, kurių kiekviename yra po vieną ar kelis įvairaus dydžio klausimynus. Siekiama užrašyti žmonių turimas žinias apie geografiją, istoriją, renkami kalbiniai, folkloro, etnografiniai duomenys. Klausimai apie kalendorines šventes patalpinti plačiausiame savo apimtimi ir klausimų ịvairove VIII skyriuje „Senovès dievai ir prietarai“, kuriame iš viso yra 1256 klausimai, iš kurių 495 tiesiogiai skirti kalendorinėms šventėms [25, 76-140]. Skyriuje pateikiamais klausimais siekiama surinkti žinių apie ikikrikščioniškosios lietuvių religijos elementus, dievus, mitines būtybes, ịvairius burtus, prietarus, atliekamus maginius veiksmus ir pan. Klausimai apie kalendorines šventes pradedami nuo bendrų žinių - prašoma išvardyti bažnytines šventes, išskirti „didžiąsias“ bei „mažąsias“ šventes, papasakoti apie tai, kaip per šventes žmonès rengiasi, puošia namus ir pan. Taip pat norima išsiaiškinti ikikrikščioniškųjų ir krikščioniškųjų švenčių sąsajas (klausimai 704-724). Toliau (725-1 183) klausimai apie šventes išdėstyti pagal kalendorinius mėnesius pradedant nuo sausio. Kiekvieną mènesị išskiriama po kelias, anot autoriaus, „ypatingesnes dienas“, tačiau medžiagos rinkèjai raginami neapsiriboti vien siūlomomis šventèmis, bet kaupti duomenis ir apie kitas „aptiktas“ šventes $[25,111]$. Užbaigiama taip pat, kaip ir pradedama, bendrais klausimais apie švenčių trukmę, ką žmonès vadina švente, tarpušvenčiu, pusšventėmis bei prašoma paaiškinti kitus, su kalendorinėmis šventėmis susijusius, terminus. Klausiama apie darbinès drausmės laikymąsi per šventes, kokias šventes švęsdavo atskirų profesijų žmonès ir pan. Baigiamieji klausimai išdèstyti poskyryje „Šventadieniai, tarpušvenčiai, pusšvente ir kitkas“ (klausimai 1 184-1 201).

Sausio mènesi išskirtos keturios šventès - Naujieji metai (6 klausimai), Triju karaliu diena (7 klausimai), Šv. Antano diena (16 klausimų), Šv. Marijos sužiedavimas (3 klausimai) [25, 111-113] (4). Kaip matome, daugiausia klausimų skirta Šv. Antano dienai. Pirmiausia, kaip kalbant ir apie visas kitas šventes, stengiamasi išsiaiškinti vietini (tarmiškąji) pavadinimą, jei šventè susijusi su konkrečiu šventuoju, to šventojo globojamas ūkio sritis, per šventes atliekamas apeigas, draudimus, spejjimus. Nemažai dèmesio skiriama vardadienio iškilmėms. Siekiama išsiaiškinti, kaip apskritai „senoveje“ švęsdavo (ar švęsdavo) vardadienius. Medžiagos rinkejjams patariama klausinejjant pirmiausia rinkti prisiminimus apie praeitị ir tik po to užrašyti informaciją apie gyvenamojo laikotarpio realijas: „Reikia įsidemèti, kad dabar tai jau švenčių taip nebešvenčia, kaip senoveje. Todèl ypačiai tyrinètojas visur privalo turèti senovę galvoje ir tik paskiau dabartį“ $[25,113]$.

Vasario mėnesį dėmesio sulaukè penkios šventès: Grabnyčios (12 klausimų), Šv. Agotos diena (6 klausimai), Užgavènès(nios) (15 klausimų), Pelenų diena (9 klausimai), Šv. Motiejaus

(4) Klausimų skaičius čia ir kitur tekste nurodomas skaičiuojant leidinyje nurodytus klausimų numerius. 
diena (4 klausimai) [25, 113-115]. Užgavėnių ir Pelenų dienos klausimai susiję pagal temą. Kreipiamas dėmesys ị tai, kokị maistą šiomis dienomis valgydavo, žaidimus žaisdavo, kaip linksmindavosi, kokių draudimų bei prietarų laikèsi. Lygindami P. Būtèno sudarytą klausimyną apie Užgavėnes su kitais tokio pobūdžio klausimynais, ypač sudarytais XX a. II pusẻje, matome, kad P. Būtènas visiškai neklausia apie persirengèlius, kaukes ir pan., o vèlesniuose klausimynuose visada rasime tokių pasiteiravimų, kartais jie yra vyraujantys.

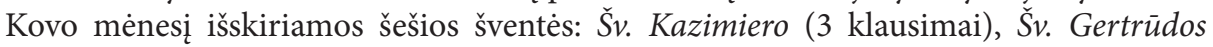
(8 klausimai), Šv. Juozapo (7 klausimai) dienos. Kovo $21 \mathrm{~d}$. vadinama Gyvuliu diena (3 klausimai), kaip šventė išskiriama Kovo 22 diena (4 klausimai) [25, 115-117]. Daugiausia klausiama apie Šv. Marijos diena (12 klausimų). Apibendrinant visų kovo ménesị paminètų švenčių klausimus, galima teigti, kad dažniausia klausiama apie ịvairių darbų draudimus ir kas gali nutikti, jeigu jų nesilaikysi, orų spejjimus, įvairius maginius veiksmus siekiant pagausinti derlių ir pan.

Balandžio mènesị klausimai pateikiami apie aštuonias šventes: Pirma aprilis (3 klausimai), Verbų diena (7 klausimai), Didžioji savaitè (1 klausimas), Didysis penktadienis (10 klausimų), Velykos (34 klausimai), Atvelykis (9 klausimai), Jurginès (19 klausimų) ir Balandžio 30 diena, kuriai suformuluoti 3 klausimai [25, 117-121]. Autorius daug dèmesio skiria ịvairiems burtams, prietarams, atliekamiems minètų kalendorinių švenčių metu, susitelkia ị tam tikrus šventès elementus, nesiekdamas užfiksuoti išsamaus, vientiso pasakojimo apie šventès eigą. Taip pat norima užrašyti kuo senesnius, su ikikrikščioniškąja kultūra susijusius elementus, pvz., vienas iš klausimų apie Jonines: „Kuri šventė senovejje šiai šventei atitiko?“ $[25,120]$.

Gegužès mėnesi išskirtos keturios šventès. Iš pradžių autorius pateikia tris klausimus apie ši mènesị sėjamus, sodinamus augalus ir avių kirpimą. Apie šventes pradedama klausti nuo $\check{S}$ v. Stanislovo dienos (2 klausimai), toliau pateikiami klausimai apie Kryžiaus dienas (12 klausimų), Šv. Urbono diena (1 klausimas) ir Šeštines (1 klausimas) [25, 121-122]. Klausiama apie minètų šventinių dienų sąsajas su ūkine veikla, ar žmonès per Kryžiaus dienas neatlieka apeigų, „neturi tam tikrų pažiūrų“, kurios nedera su krikščioniškuoju mokymu, kaip buvo einama į kapus, ką ten žmonès veikdavo ir pan.

Birželio mènesị išskirtos septynios šventès: Sekminès (4 klausimai), Šv. Vito diena (2 klausimai), Dievo kūno (3 klausimai), Joniniu išvakarès (34 klausimai), Joninès (10 klausimų), Septynių brolių miegančių diena (27 d.) (4 klausimai), Petrinés (6 klausimai) [25, 122-126]. Kaip matome, didžiausias dėmesys skiriamas Joninėms. Ši šventė skaidoma i dvi dienas. Klausimų sudarytoją labiausiai domino Joninių dienos išvakarès. Siekiama surinkti ne tik etnografinių, bet ir folkloro duomenų. Klausiama, kokios dainos apskritai dainuojamos Joninių išvakarèse, kokias dainuodavo atliekant tam tikrus apeiginius veiksmus, kokių pasakų, padavimų žmonės žino apie paparčio žiedą ir pan. Taip pat klausiama apie ịvairias apeigas, burtus, vaistažolių rinkimą, raganavimą ir kt. Klausimai apie Joninių dieną (24 d.) - Joninių išvakarių klausimų tąsa. Teiraujamasi apie jonvabalius ir jų naudą gydymui, raganų suaktyvejimą ir pan.

Liepos mènesi išskiriamos penkios šventès: $\check{S} v$. Marijos aplankymas (4 klausimai), Septyniu broliu mieg. diena (10 d.) (3 klausimai), Škaplierna (4 klausimai), Šv. Jokūbo diena (4 klausimai), $\check{S} v$. Onos diena (9 klausimai) [25, 126-127]. Kaip matome, apie paminètas šventes formuluojama tik po kelis klausimus, siekiama išsiaiškinti ịvairius prietarus, tikejjimus, susijusius su pirmuoju derliumi, ùkio darbais, orų spejjimu ir pan. Tik du apie Šv. Onos dieną pateikti klausimai yra konkrečiai susiję su šia švente. Kitais klausimais siekiama sužinoti apie griaustinį, žaibą ir su tuo susijusius tikejjimus. 
Rugpjūčio mènesị taip pat išskiriamos penkios šventès: ̌̌v. Marijos Snieginès diena (4 klausimai), Šv. Lauryno diena (10 klausimų), Žolinè (5 klausimai), Baltramiejaus diena (4 klausimai), Šv. Jono galvos nukirtimas (3 klausimai) [25, 127-128]. Pradžioje suformuluoti bendri klausimai apie ugni, o toliau pereinama prie klausimų, skirtų konkrečiom kalendorinėm šventèm. Daugiausia dėmesio skiriama Šv. Lauryno dienai, siekiama atskleisti šios dienos sąsajas su ugnimi, jos gerbimu, teiraujamasi, ar girdèjo buvus „ugnies motiną“ [25, 127]. Dauguma klausimų apie kitas šventes susiję su ūkine veikla, pirmuoju derliumi, arba tiesiog domimasi, ką žmonès žino apie šventę, ar ji reikšminga, pavyzdžiui, ar reikšminga Šv. Jono galvos nukirtimo diena.

Spalio mėnesị išskiriamos keturios šventès: Angelų sargų diena (3 klausimai), Rožančiava (3 klausimai), Dievu dienos (9 klausimai), Simijudai (Simajudas) (3 klausimai) [25, 129130]. Daugiausia klausimų suformuluota apie Dievų dienas. Norima surinkti duomenų apie tai, kada prasideda ir kada baigiasi šios dienos, ką žmonės jų metu veikia, kokie galiojo draudimai, kas nutikdavo jų nesilaikant ir pan. Kitų švenčių metu, matyt, kiek ženklesnių apeigų nebuvo atliekama arba klausimų sudarytojas jų nežinojo, todėl tiesiog klausiama: ar žmonės žino kokių apeigų, prietarų, kaip jie tą šventę vadina ir pan.

Lapkritị išskiriamos septynios šventès: Visu Šventuju diena (2 klausimai), Vèlinès (Zadūšnosios) (8 klausimai), Šv. Elžbietos diena (1 klausimas), Šv. Martyno išvakariu die$n a$ (6 klausimai) ir $\check{S} v$. Martyno diena (4 klausimai), $\check{S}$. Kotrynos diena (3 klausimai), $\check{S}$ v. Andriejaus diena (2 klausimai) [25, 130-132]. Daugiausia pateikiama klausimų apie Vèlines. Beveik visais klausimais siekiama surinkti medžiagą apie vèles, jų vardus, elgesį, apsilankymą pas gyvuosius, maitinimą. Palyginti daug demesio skiriama Šv. Martyno dienai. Klausiama apie šventès išvakarèse atliekamus apeiginius veiksmus, mįslių minimą, tam tikrų valgių draudimą ir šios dienos sąsajas su Kotrynos bei Andriejaus dienomis.

Gruodžio mènesị išskiriamos septynios šventès: $\check{S} v$. Barboros diena (2 klausimai), $\check{S}$ v. Mikalojaus diena (8 klausimai), Šv. Marijos nekalto prasidejjimo diena (2 klausimai), Šv. Liucijos (Lucès) diena (2 klausimai), Kūčios (arba Kūčia) (24 klausimai), Kalèdos (6 klausimai), Naujuju Metu priešvakaris (12 klausimų). Po Naujųų metų atskirai išskirta Gavenia (8 klausimai) [25, 132-135]. Šv. Mikalojaus dienai skirti klausimai dėmesį sutelkia ị „šeimynos" išleidimą, atsisveikinimą, atsiskaitymą ir pan. Daugiausia klausimų apie Kūčias: šio laikotarpio burtus, spejjimus, darbo draudimus, nepaprastus nutikimus ir pan. Keli klausimai yra apie Kūčių valgius ir stalo padengimą. Nuo klausimų apie konkrečius šventès elementus pereinama prie raginimo aprašyti „,visas „kūčiav(oj)imo“, susèdimo už stalo, kalbų, linkejjimų, i̇ pirtị èjimo, būrimo ir kt. apeigas ir papročius“ [25, 134]. Informacijai apie Kalèdas skiriama gerokai mažiau dèmesio. Klausiama apie šiuo laikotarpiu atliekamas apeigas, valgomus valgius, žaistus žaidimus, dainuotas dainas, „ar neidavo persitaisę pakiemiais“ ir pan. Dauguma klausimų apie Naujųjų metų išvakares skirti išsiaiškinti, kokie būrimai, spejjimai, maginiai veiksmai buvo atliekami šiuo metu.

Apibendrinant P. Būtèno sudarytos programos klausimus, skirtus etnografinei medžiagai apie kalendorines šventes rinkti, reiktų pabrěžti akivaizdžią tendenciją - surinkti kuo senesnius duomenis, pirmiausia žmonių atsiminimus, girdètus pasakojimus apie „senovès“ šventes ir tik po to užrašyti gyvenamojo laikotarpio medžiagą. Reikšmingą vietą užima klausimai, kuriais siekiama išsiaiškinti ikikrikščioniškųjų švenčių elementus, dažnai klausiama tik apie atskiras šventès detales - burtus, prietarus, spejjimus. Klausimai formuluojami irgi skirtingai: vieni - labai abstraktūs, platūs, pavyzdžiui, „kokios apeigos esti per Sekmines?" [25, 122], kiti - konkretūs, apie tam tikrą šventės elementą, apeigą, veiksmą ar 
pan. Greičiausiai tai priklausė nuo sudarytojo sukauptos informacijos apie konkrečią šventę, metodologinės tradicijos. Reiktų manyti, kad išskirtas šventes autorius laiko svarbiomis arba nykstančiomis, nes pratarmèje, rašydamas apie paskirtį, pažymi, jog programoje nurodoma, „kas ypačiai reikalinga rinkti ir tai tučtuojau, né akimirkos nebelaukiant“ $[25,4]$.

Metodikos srityje itin aktyvi buvo Šiaulių kraštotyros draugija [26, 24]. Draugijos nariai rengè, spausdino ir platino programas bei anketas etnografinei medžiagai rinkti. P. Bugailiškio teigimu, anketos buvo siuntinejjamos draugijos bendradarbiams, mokytojams, gydytojams, kunigams, šviesesniems ūkininkams ir kt., tačiau atsakymų sulaukta nedaug $[3,71]$. Anot V. Miliaus, dauguma Šiaulių kraštotyros draugijos sukurtų anketų buvo teminès su numeruotais klausimais. 1931-1942 m. išleista 22 anketos ir tik viena skirta kalendorinėms šventėms - „Kaledų ir N. metų švenčių apeigų anketa“ (1932) [33, 129130]. Skaitydami Šiaulių kraštotyros draugijos 5 metų veiklos apžvalgą $[3,71]$, randame žinių ir apie tai, kaip draugijai pagal sudarytas anketas sekèsi rinkti etnografinę medžiagą. Pavyzdžiui, buvo išsiuntinètos 273 „Kalèdų ir N. metų švenčių apeigų anketos“, tačiau gauti tik 23 atsakymai (5). P. Bugailiškis kritikavo vangų mokytojų atsiliepimą i i išsiuntinètas anketas ir gyrè moksleivius, kurie kartais atsiunčia „neblogos medžiagos“, ypač tada, kai anketose smulkiai ir aiškiai pateikiami klausimai ir uždaviniai $[3,71]$. Tačiau iš išsiuntinètų ir gautų užpildytų anketų santykio matome, kad gyventojai nebuvo aktyvūs, jog pagrindiniai etnografinių duomenų rinkèjai buvo patyrę draugijos korespondentai, kurie, anot P. Bugailiškio, medžiagą surinkdavo geriausiai $[3,71]$.

Nepaisant minètų P. Bugailiškio nusiskundimų dèl mokytojų vangumo dirbant kraštotyrinị darbą, matyt, mokytojų bei mokinių pagalba buvo ženkli, renkant etnografinę medžiagą i juos dèta vilčių. Antai J. Balio anketa, skirta medžiagai apie kalendorines šventes rinkti, neatsitiktinai buvo išspausdinta pedagoginès pakraipos laikraštyje „Tautos mokykla“ [1, 467-468]. J. Balys kreipèsi į visus laikraščio skaitytojus bei mokytojus, ypač tuos, kurie gyvena kaime, ragindamas rinkti duomenis patiems ir skatinti tai daryti savo mokinius. Iš toliau pateikiamo teksto aiškejja, kad mokytojai bei mokiniai jau ir anksčiau yra talkinę renkant etnografinę medžiagą. J. Balys užsimena, kad „prieš kelis metus“ „daug labai gražios medžiagos“ surinko Panevėžio mokytojų seminarijos moksleiviai (6). Tačiau, matyt, neišvengta ir netinkamo fiksavimo atvejų. J. Balys, remdamasis jau sukaupta etnografinès medžiagos rinkimo patirtimi, pateikè mokytojams nurodymus dèl duomenų užrašymo: „Pradžios mokyklų mokytojai turètų užrašyti patys, nes jų mokiniai, kaip rodo patyrimas, tokio darbo dar nesugeba tinkamai atlikti. Tuo tarpu aukštesnèse mokyklose galètų užrašyti ir patys mokiniai, mokytojo gerai painformuoti“ [1, 468]. Pridedama anketa, anot J. Balio, turètų padèti suprasti, ł̇ ką reikia atkreipti dèmesị. Anketą sudaro 32 klausimai. Pagrindinis dėmesys skiriamas Kūčioms, tačiau ịtraukti klausimai ir apie Kalėdas, Naujuosius metus, apimamas visas šventinis laikotarpis nuo Kūčių iki Trijų karalių. Pateikiamų klausimų spektras gana platus. Klausiama apie Kūčių

(5) „Kaledų ir N. metų švenčių apeigų anketoje“ yra 19 klausimų. Iš jų 8 apie Kūčias. Daugiausia dèmesio skiriama Kūčių stalui - kokie ruošiami valgiai, kiek jų ruošiama, kaip padengiamas stalas, kada pradedama valgyti, koks maisto valgymo eiliškumas ir pan. Po 4 klausimus skiriama Kaledoms ir Naujiesiems metams bei 3 bendri, su šventemis susiję, klausimai. Pabaigoje prašoma aprašyti Kalèdų ir Naujųų metų šventes „,aplamai“. Šiaulių „Aušros“ muziejaus Etnografinis archyvas, anketa Nr. 3.

(6) Greičiausiai J. Balio minimas etnografinès medžiagos rinkimas sietinas su P. Būtèno veikla, kuris nuo 1925 m. pradėjo dirbti Panevėžio mokytojų seminarijoje. Jo skaitytos paskaitos tautosakos, tautotyros temomis buvo gausiai lankomos. Kilo sumanymas suorganizuoti kuopelę, kuri rinktų tautosaką ir senienas. Kuopelè pasivadino „Lietuvių kalbos mylètojų draugija“. I ją užsirašè 70 žmonių [27, 10]. 
vardo aiškinimą, pasiruošimą Kūčių vakarienei, stalo padengimą bei valgių gaminimą, ruošos darbų pasiskirstymą tarp šeimos narių, socialinę elgseną (elgesị su namiškiais, svečiais, samdiniais), religines apeigas, įvairius būrimus, spejjimus ir kt. Autorius pažymi, kad pateiktas klausimynas neapima visų rūpimų temų, greičiausiai buvo pateikti tik labiausiai J. Balị dominę klausimai. Vèliau šie klausimai su nežymiais pakeitimais bei praleidus klausimą apie Kalèdų valgius buvo perspausdinti 1936 m. išleistame Lietuvių tautosakos archyvo leidinyje „Tautosakos rinkejjo vadovas“, skyriuje „Kalendoriniai papročiai, prietarai ir burtai“ [45, 69-80]. Ši klausimų grupe pavadinta „Kalėdos ir Naujieji Metai“. Minètame leidinyje taip pat pateikiami klausimai, skirti duomenims apie kitas žymesnes šventes - Užgavėnes (15 klausimų), Velykas (33 klausimai), Sekmines (6 klausimai), Jonines (13 klausimų), Vèlines (7 klausimai) - rinkti. Su konkrečių šventųjų pagerbimu susijusios šventès apjungiamos ị bendrą klausimų grupę, pavadintą „Šventųjų kultas" (16 klausimų) [45, 78]. Klausimyno autorius išskiria tokius šventuosius: šv. Jurgis, šv. Antanas, šv. Agota, šv. Juozapas, šv. Ona, šv. Izidorius, šv. Laurynas, šv. Andriejus, šv. Elijas, šv. Martynas, šv. Mykolas. Klausimai(as) (jų gali būti nuo 1 iki 3) apie tam tikrą šventąji žymimi vienu numeriu. Greičiausiai klausimynų sudarytojas pastarąsias kalendorines šventes laikè ne itin reikšmingomis, todẻl ir dèmesys apie jas renkant medžiagą gerokai menkesnis nei, pavyzdžiui, apie Jonines, kurios taip pat susijusios su katalikų šventuoju. Kadangi norima surinkti medžiagą apie kalendorinių švenčių papročius, prietarus ir burtus, todèl katalikiškasis švenčių aspektas nesureikšminamas. Antraštèje nurodytas kalendorinès šventès pavadinimas ne visiškai atitinka klausimus. Dažniausiai klausiama apie visą šventinį ciklą, pavyzdžiui, klausimyne apie Užgavėnes rasime klausimų ir apie Pelenų dieną arba siūlymą rinkti medžiagą apie Šv. Velykas pradedant klausimais apie Verbų sekmadienị, o užbaigti - Atvelykiu. „Tautosakos rinkejjo vadove“ skelbiamas 121 numeruotas klausimas apie kalendorines šventes (395-516), tačiau realiai jų gerokai daugiau, kadangi dažnai vienu numeriu pažymèti keli klausimai [45, 69-80]. „Vadove“, kaip ir anksčiau analizuotoje P. Būtèno programoje, pateikti klausimai nesuabsoliutinami, o renkant medžiagą laikomi gairèmis: „žemiau dedamieji klausimai yra tik labai bendri rèmai. Jie turès rinkèjus tik supažindinti, ko maž daug ieškoma ir kas reikia užrašinèti, $\mathfrak{i}$ ką ypatingai reikia kreipti dèmesys, tuo tarpu rinkejjas ras daug dalykų, kurių tie klausimai ir neapims - juos taip pat reikia užrašyti“ $[45,30] .1940$ m. išleistame antrajame „Tautosakos rinkèjo vadovo" leidime tiesioginių klausimų apie kalendorines šventes nèra, po keletą netiesioginių klausimų galime rasti apie ugnies papročius, ūkio darbus, nuimamą derlių [46, 116-119].

Apibendrinant medžiagos rinkimo priemones, skelbtas iki Antrojo pasaulinio karo, reikia pažymèti, kad P. Būtèno sudarytoje „Lietuvių tautotyros žinių ir senienų rinkimo programoje“ bei J. Balio redaguotame „Tautosakos rinkejo vadove“ (1936) paskelbta daugiausia tiesioginių klausimų, skirtų duomenims apie kalendorines šventes rinkti, - atitinkamai 495 ir 121. Kaip matome, P. Būtèno sudarytoje „programoje“ kalendorinèms šventèms skirtų klausimų ženkliai daugiau, jie apima daug daugiau švenčių, aiški struktūra - klausimai apie šventes išdèstomi remiantis kalendoriumi, išrenkamos žymiausios kiekvieno mėnesio šventès. Nors abiejuose leidiniuose siekiama surinkti medžiagą apie kalendorines šventes, tačiau P. Būtèno „programa“ skirta palengvinti „etnografų rinkèjų“ $[25,4]$ darbą ir pateikiamų klausimų pagalba išsiaiškinti senovès ir šių dienų ịvairių švenčių šventimą bei apeigas $[25,111]$, o J. Balio redaguotas „Vadovas“ skirtas rinkti tautosaką, iš skyriaus antraštės galime suprasti, kad dèmesys bus sutelktas ị tautosakos 
objektą - kalendorinius papročius, prietarus ir burtus. Taigi, šios dvi medžiagos rinkimo priemonès yra skirtos atskirų mokslų empiriniams duomenims rinkti. Tai lèmé juose pateikiamų klausimų pobūdị. Kita vertus, reiktų sutikti su tyrinėtojų nuomone, kad papročiai, tikèjimai gali būti tiek etnologijos, tiek tautosakos mokslų objektas $[35,15]$. Be to, nemaža dalis „vadove“ pateiktų klausimų apie kalendorines šventes skirti etnografinei medžiagai fiksuoti.

\section{ETNOGRAFINĖS MEDŽIAGOS APIE KALENDORINES ŠVENTES RINKIMO PRIEMONĖS SOVIETMEČIU}

Po Antrojo pasaulinio karo vis aktyviau vykdyti lauko tyrimai, kurių pagrindine darbo priemone tapo klausimynai. Sparčiai besikeičiantis kaimo kraštovaizdis, buitis vertẻ skubėti išsaugoti nykstančius materialinès kultūros elementus, aprašyti tradicinio ūkininkavimo formas, amatininkystę ir kitas kaimo realijas. I pagalbą buvo pasitelkti išsilavinę gyventojai ir ypač kraštotyrininkai. Pastarieji sovietmečiu daug nuveikè rinkdami empirinę medžiagą. Leidinyje „Kraštotyra“ buvo spausdinami metodiniai patarimai. Jau pirmuosiuose „Kraštotyros“ numeriuose (nuo 1963 iki 1971) buvo metodinis skyrelis „Mes patariame“, vèliau pervadintas $i \mathfrak{i}$ „Metodiniai nurodymai“. Jame spausdinti patarimai, kaip rinkti medžiagą, ir klausimynai. Per minètą laikotarpi buvo išspausdinti 22 mokslininkų bei kraštotyrininkų parengti metodiniai patarimai ir klausimynai etnografine tematika [26, 32-33]. Tačiau kalendorinių švenčių tema dèmesio nesulaukè. „Kraštotyroje“ paskelbtoje V. Miliaus bibliografineje rodyklejje tarp šešiolikos 1950-1962 m. parengtų programų ir anketų nèra nè vieno pavadinimo, bent kiek susijusio su kalendorinèmis šventėmis [34, 133-135]. Klausimynai, anketos etnografinei medžiagai apie kalendorines šventes rinkti nesudarinèti ir XX a. 7-ajame dešimtmetyje. 1963-1969 m. etnografinių anketų bibliografijoje tarp 59 anketų pavadinimų [30, 351-355] taip pat nèra nè vieno bent kiek susijusio su kalendorinėmis šventėmis. Vyrauja etnografinès medžiagos rinkimo priemonès, skirtos materialinès kultūros faktams fiksuoti. Išanalizavus 1945-1973 m. etnografinių anketų bibliografiją, paaiškèjo, kad iš 109 anketų taip pat nèra nè vienos, skirtos etnografinei medžiagai apie kalendorines šventes rinkti [29], tačiau po vieną kitą klausimą apie kalendorines šventes galime rasti kitokios tematikos anketose. Vienas klausimas yra J. Buzo anketoje „Rinkime duomenis apie Vilniaus verbas ir jų gamintojus“ [4, 335-336], jame Vilniaus verbos siejamos su Verbų sekmadieniu. Bibliografijoje paminètuose A. Vyšniauskaitès „Nurodymuose rinkti medžiagai „Europos etnografiniam atlasui“ iš 18 klausimų 4 susiję su kalendorinėmis šventèmis ar jų papročiais. Pagrindinis dèmesys skiriamas duomenims apie Kalėdinio laikotarpio persirengèlius užrašyti. Kitais „nurodymuose“ pateiktais klausimais siekiama surinkti informaciją apie apeiginès ugnies deginimo formas, susiejant jas su kalendorinèmis šventemis - Naujaisiais metais, Joninėmis. „Nurodymuose“, neminint Velykų šventės vardo, yra du klausimai apie šios šventės papročius - kiaušinių dažymą, marginimą, žaidimus su jais [47]. Minètų „nurodymų“, kaip beje ir kitų medžiagos rinkimo priemonių, klausimų numeracija neatitinka realaus klausimų skaičiaus. Dažnai vienu numeriu pažymèti keli tarpusavyje susiję (patikslinantys) paklausimai, todèl realus klausimų skaičius praktiškai visada yra didesnis. Pavyzdžiui, 15 klausimą „Kokie buvo Kalèdų laikotarpio papročiai. Ar buvo valkiojamas rąstas ir kada, čigonaujama, vaikščiojama apsitaisius kaukèmis. Kada, kas / vyrai, vaikai, paaugliai, moterys/ ir kaip persirengę vaikščiodavo. Iš ko buvo padarytos kaukès. Jas aprašykite" galima suskaidyti į mažiausiai aštuonis atskirus klausimus arba teiginius. Taigi, 
remiantis A. Vyšniauskaitès sudarytais „nurodymais“, jau buvo galima surinkti gana nemažai informacijos apie šventes.

1974-1982 m. bibliografinèje anketų rodyklèje skelbiami 66 anketų pavadinimai [32]. Tiesiogiai su kalendorinèmis šventèmis susijusi viena anketa - „Žiemos periodo kalendoriniai papročiai“ [28]. 1982 m. ją sudarè I. R. Merkienè ir V. Čiubrinskas etnografinei medžiagai apie žiemos periodo kalendorinius papročius rinkti. Bibliografinèje rodyklèje minima ir R. Giedrienès anketa „Mirusiųjų pagerbimo papročiai kapinėse“. Nors perskaitę pavadinimą galime pamanyti, kad priemonė skirta etnografinei medžiagai apie Visų šventujjų ir Vèlinių dienas rinkti, tačiau joje yra tik du klausimai apie „rudeninị mirusiųjų pagerbimą“, kuriais siekiama išsiaiškinti apeigų pavadinimą („Kokios apeigos kapinèse būdavo atliekamos rudenị ir kaip tos apeigos vadinosi?"), elgetų vaidmenị jų metu, ugnies reikšmę mirusiųjų pagerbimo apeigose bei žvakių deginimo kapinèse tradiciją [9].

XX a. 9-ajame dešimtmetyje išleistoje M. Sakalauskienės knygeleje „Švenčių tyrimas ir fiksavimas" [38] pateikiami metodiniai nurodymai, skirti sovietinių švenčių realijoms fiksuoti. Šventès suprantamos kaip komunistinio auklejjimo priemonè. Didžiausias dèmesys skiriamas politinèms bei darbo šventėms, kurios turẻjo užtikrinti idèjinį-politini ir darbinị auklejimą $[38,16]$. Leidinyje pateikti ne tik teoriniai samprotavimai apie sovietines šventes, bet ir klausimynas šių švenčių realijoms nustatyti. Jame šventė suskirstyta $\mathfrak{i}$ tris struktūrines dalis - „iškilmès“, „reginiai“, „pramogos“. Kiekvienoje dalyje nurodoma galima veikla ir prašoma ją aprašyti [38, 24-25].

Po Antrojo pasaulinio karo aktyvūs etnografinès medžiagos rinkejjai buvo Vilniaus universiteto studentai. P. Dundulienès teigimu, pirmoji žvalgomoji ekspedicija po Vilniaus kraštą buvo surengta 1948 metais. [8, 81-95]. Autorè rašo, kad „vykdant ekspedicijas, jau pirmaisiais metais buvo paruoštos specialios anketos, apimančios beveik visas liaudies buities ir kultūros sritis. Ruošiant anketas, ypatingas dèmesys buvo kreipiamas ị materialinę liaudies kultūrą, tačiau nebuvo pamiršta ir dvasine “ $[8,84]$. Anketas sudarinèjo Vilniaus universiteto darbuotojai, tačiau naudotasi ir „Lietuvos TSR paminklų apsaugos bei kraštotyros draugijos paruoštomis anketomis“ $[8,90]$. Anot P. Dundulienès, 1970-1973 m. ji parengè anketų apie kalendorines ir agrarines apeigas, kurios, kaip ir daugelis kitų, buvo rankraštinès $[8,89]$. Autorè nenurodo nei anketų pavadinimų, nei jų skaičiaus.

Apibendrinant sovietmečiu išleistas etnografinès medžiagos apie kalendorines šventes rinkimo rekomendacijas reiktų pasakyti, kad buvo tik vienas leidinys, išspausdintas gana vèlai, tik $1982 \mathrm{~m}$. Vis dèlto duomenys apie kalendorines šventes buvo renkami ir sovietmečiu, klausimai apie jas būdavo įterpiami ị kitokios tematikos medžiagos rinkimo priemones, arba naudotasi rankraštiniais klausimynais. Sovietmečiu rankraštinès medžiagos rinkimo priemonès apie kalendorines šventes buvo sudarinèjamos bent jau nuo XX a. 6-7-ojo dešimtmečių. Tokią prielaidą leidžia daryti rankraštynuose (Vilniaus universiteto bibliotekos Rankraščių skyriaus 81 fonde ir Lietuvos istorijos instituto Bibliotekos rankraštyno Etnologijos skyriaus fonde, ir kt.) saugomi etnografiniai aprašai apie kalendorines šventes bei P. Dundulienès Vilniaus universitete vykusių etnografinių ekspedicijų aprašymai. Anot P. Dundulienès, rankraštinius anketų variantus apie kalendorines apeigas ji parengė XX a. 8-ajame dešimtmetyje (aptartose V. Miliaus anketų bibliografijose tokios anketos neminimos. Galbūt todèl, kad jos nebuvo išspausdintos).

Faktas, kad per visą sovietmetị (iki 1982) autorei nepavyko aptikti nė vienos publikuotos priemonès, skirtos tiesiogiai medžiagai apie kalendorines šventes rinkti, ar bibliografinèse rodyklèse paminèto tokios priemonès pavadinimo, rodo, kad jei jos ir buvo kuriamos, 
tai bent jau oficialioje mokslo institucijų veikloje nefiksuotos. Sovietmetis buvo nepalankus laikotarpis kurti medžiagos apie kalendorines šventes rinkimo priemones ir šia tema rinkti etnografinę medžiagą. Daug ịtakos turèjo ir ateistinė propaganda. Tradicinès lietuvių šventès glaudžiai susijusios su katalikiškuoju kalendoriumi, todèl doméjimasis jomis neatitiko sovietinio ideologinio turinio (7).

\section{ETNOGRAFINĖS MEDŽIAGOS APIE KALENDORINES ŠVENTES RINKIMO PRIEMONĖS ATGIMIMO IR NEPRIKLAUSOMOS LIETUVOS LAIKOTARPIU}

Kad tyrejjus, kraštotyrininkus ir kitus, besidominčius lietuvių kultūra, asmenis domino dvasinès kultūros palikimas, kalendorinių švenčių tradicijos, rodo suaktyvėjęs medžiagos rinkimo priemonių kūrimas, duomenų apie kalendorines šventes rinkimas Atgimimo laikotarpiu ir Lietuvai atgavus nepriklausomybę (1990). Daugejo mokslinių tyrimų. Tyrèjai, analizuodami kalendorines šventes, turejo ne vien tik pažintinių teorinių interesų, bet ir rekonstrukcinių tikslų: „ką ne ką iš tèvų palikimo grąžinti jaunajai kartai“ $[17,4]$. Vienas iš tokių tyrinètojų buvo J. Kudirka. Jis rinko medžiagą apie kalendorines šventes, o savo sudarytas anketas stengèsi visuomenèje kuo plačiau paskleisti. J. Kudirkos sudarytos anketos Lietuvos kultūros centro išleistos atskiru leidiniu [23], paskelbtos rajoniniuose laikraščiuose, išplatintos kultūros namuose, kaimiškosiose parapijose, senelių namuose, kraštotyrininkams ir pan. Tautinio atgimimo laikotarpiu žmonės gana aktyviai atsakinejjo i J. Kudirkos išplatintas anketas ir, anot autoriaus, tie atsakymai sudare jo kalendorinių švenčių analizès pagrindą (8). Anketos spausdintos ir autoriaus apibendrintuose darbuose apie kalendorines šventes. Leidinyje „Kūčių stalas“ skelbiamos dvi anketos - „Kūčios ir Kalèdos“ ir „Velykų šventès“ [15, 45-56]. 18 anketų paskelbta knygelèje „Papročiai ir kaimo kultūra", iš kurių 15 skirtos kalendorinèms šventèms [19]. Leidinyje autorius glaustai aprašo „metų šventes“, pradėdamas Užgavėnėmis ir baigdamas Trijų karalių švente. Po kiekvieno aprašymo pateikiama anketa, skirta etnografinei medžiagai apie šventę rinkti. Knygeleje „Papročiai ir kaimo kultūra“ pateiktos anketos yra nedidelès apimties - nuo 7 iki 14 klausimų. Formuluojant klausimus stengiamasi išsiaiškinti šventès papročius, apeigas, eigą, jos dalyvius bei jų veiksmus šventès metu. Klausiama, ką per konkrečias šventes veikdavo skirtingų amžiaus grupių, lyčių asmenys. Matyt, stengiantis kompleksiškai surinkti duomenis, anketose yra klausimų ir apie per šventes dainuotas dainas, sakytas oracijas, šoktus šokius, žaistus žaidimus ir pan. Kai kuriose anketose užduodami klausimai apie kelias, tarpusavyje laiko ir / ar apeigų atžvilgiu susijusias, šventes. Pavyzdžiui, anketoje apie Užgavènes po vieną klausimą įterpta ir apie Pelenų dieną bei pusiaugavèni $[19,27]$. Kai medžiagos rinkimo priemonè sudaroma turint konkretų tikslą, tada užduodami tyrejjui svarbiausi, geriausiai atskleidžiantys tyrimo objektą ir problematiką, klausimai.

(7) Lietuvos istorijos instituto Etnologijos skyriuje saugomoje anketoje „Bendros žinios apie šeimos kultūrinị lygị (praeity ir dabar)“ yra klausimas, kaip šeimoje švenčiamos šventès. Anketos autorius šventes skirsto ị „tarybines“ (kaip pavyzdị nurodo Gegužès 1-ąją, Konstitucijos dieną, Spalio revoliucijos metines), „kolūkio šventes“ (derliaus diena, sėjos pabaigtuvès), „liaudies šventes“ (Užgavènès, Naujieji metai), „bažnytines šventes“ (Velykos, Kalèdos, „atlaidai“) ir „šeimos šventes“ (vardinès, gimimo diena, jubiliejai). Remiantis šia klasifikacija, su katalikiškuoju kalendoriumi nesusijusios šventès (Užgavėnès, Naujieji metai) patenka ị ideologiškai palankią „liaudies“ terpę, o kitos - „bažnytinès“ - šventès sovietmečiu buvo netoleruojamos. Autorè naudojosi rankraštiniu šios anketos variantu.

(8) Kartais autorius pratarmejje nurodo, kad darbo pagrindą (70 \% medžiagos) sudaro žinios, surinktos pagal jo sudarytą anketą $[16,4 ; 17,4]$. 


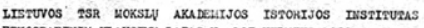

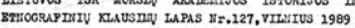

albinas rexustrus

veray arsigos in PAzzoctaI

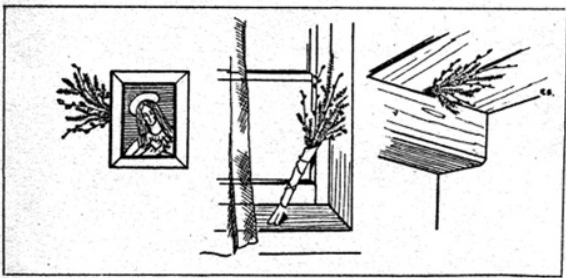

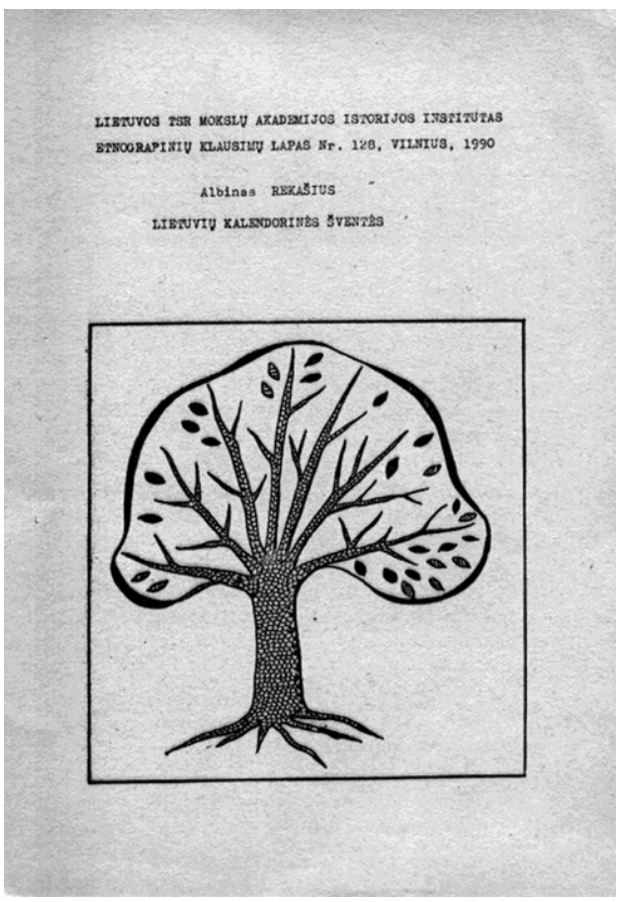

Pav.„Etnografinių klausimų lapų“ titulinių puslapių pavyzdžiai. lliustravo Rita Butvilienė

Istorijos instituto Etnografijos skyriaus (nuo 1996 - Etnologijos) darbuotojams medžiagos rinkimo priemonès būdavo atspausdinamos atskiruose lapuose (brošiūrose) (9), pavadintuose „etnografinių klausimų lapai“. Paprastai buvo spausdinamos tik su planiniais mokslininkų darbais susijusios medžiagos rinkimo priemonès, tačiau jomis naudojosi ne tik tyrèjai. „Etnografinių klausimų lapai“ buvo dalijami žmonėms ir prašoma raštu atsakyti i juose esančius klausimus bei medžiagą atsiųsti klausimų lapo gale nurodytu adresu. Kartais būdavo nurodomas Istorijos instituto Etnografijos skyriaus telefono numeris, jeigu kiltų kokių klausimų ar neaiškumų. Lietuvos Istorijos instituto Etnografijos skyriaus darbuotojai XX a. 9-10-uoju dešimtmečiais pradejo aktyviau sudarinèti etnografinius klausimynus, skirtus kalendorinėms šventėms ar tam tikriems jų aspektams tirti. XX a. 9-ojo dešimtmečio pabaigoje A. Rekašiaus sudarytame klausimų lape „Verbų apeigos ir papročiai“ siekiama surinkti duomenis apie Verbų dieną, verbos paskirtị, panaudojimo būdus, su verba susijusius papročius, elgesi su sakramentalija ir pan. [37]. Kita minèto autoriaus anketa jau skirta kompleksiniam kalendorinių švenčių tyrimui [36]. Klausimyno pradžioje autorius prašo aprašyti pasirinktą vieną iš 14 išvardytų švenčių (10) „pagal pateiktus klausimus“. Klausimų lapą sudaro 20 formalių klausimų, pritaikytų aprašyti bet kurias (iš 14 nurodytų) šventes.

(9) Dažniausiai klausimynai būdavo atspausdinami A4 formato horizontaliame popieriaus lape. Lapas sulenkiamas pusiau ir pirmame (tituliniame) puslapyje užrašomas institucijos pavadinimas, klausimyno sudarytojo vardas, pavardè, klausimyno pavadinimas ir kartais nupiešiamas koks nors grafiškas paveikslèlis.

(10) Išvardijamos šios šventės: Kūčios, Kalėdos, Naujieji metai, Trys karaliai, Užgavėnès, Verbos, Velykos, Šeštinès, Sekminès, Jurginès, Joninès, Žolinè, Visi šventieji, Vẻlinès. 
Tai retas metodinis sprendimas, paprastai tyrëjai formuluoja individualizuotus klausimus, susijusius su konkrečiu tyrimų objektu, siekiant išsiaiškinti ne tik formalius bruožus, tačiau ir specifinius, išskirtinius faktus, kitaip sakant, ne tik formą, bet ir turinį. XX a. 10-ajame dešimtmetyje išsamų klausimyną (43 klausimai), skirtą atlaidų tyrimams, sudarẻ S. Gutautas ir Ž. Šaknys (11). Autoriai siekè surinkti žmonių atmintyje išlikusias senųjų atlaidų nuotrupas. Daug dèmesio skiriama ịvairiems žmonių tarpusavio bendravimo, socialiniams aspektams. Rinkti etnografinę medžiagą apie atleidus skirtas ir J. Mardosos klausimynas „Šiuolaikiniai atlaidai“ [26, 89-90], kuriame suformuluotais klausimais siekiama atskleisti respondentų individualų santykį, individualias atlaidų šventimo sampratas. Autorius nurodo, kad, siekdamas medžiagą susieti su tradicinių atlaidų tyrimais, kai kuriuos klausimus paèmė iš anksčiau minèto S. Gutauto ir Ž. Šaknio klausimyno. Abu klausimynai papildo vienas kitą, jais vadovaujantis surinkta etnografinè medžiaga turètų tyrejui atskleisti išsamų atlaidų istorinès raidos vaizdą. Jau minètoje J. Mardoso sudarytoje knygoje „Apie metodiką ir metodinès priemonès“ skelbiami 23 ịvairios apimties ir temų klausimynai. Tik maža dalis, trys iš jų, tiesiogiai susiję su kalendorinėmis šventėmis: „Šiuolaikiniai atlaidai“ (J. Mardosa), „Sovietmečio šventès ir tradicijos“ (R. Kuodytė, J. Mardosa) ir „Šv. Valentino diena“ (Ž. Šaknys) [26, 89-90; 128-133]. Tik vienas klausimynas skirtas etnografinei medžiagai apie lietuvių tradicines kalendorines šventes rinkti, o pasitelkus kitus du norima surinkti etnografinę medžiagą apie lietuviams nebūdingas, primestas ar kultūrinių mainų keliu ị Lietuvą atejjusias šventes. Nors klausimynų sukūrimo laikas nenurodytas, tačiau sprendžiant iš jų turinio reiktų manyti, kad jie buvo sudaryti XX a. pabaigoje. Klausimynas „Sovietmečio šventès ir tradicijos“ [26, 129 - 133] skirtas etnografinei medžiagai apie „Revoliucines ir valstybines“, „Profesines šventes“, „Moters“ ir „Armijos“ dienas užrašyti. Siekiama atskleisti žmonių požiūrị ị sovietmečiu Lietuvoje ịvestas, sukurtas šventes, jų šventimo specifiką bei tvarumą posovietiniu laikotarpiu. Per asmeninę žmonių patirtị mėginama pažvelgti ị tokių švenčių turinio individualų ịprasminimą.

Ž. Šaknys pirmasis pradejo tyrinèti Lietuvoje po nepriklausomybės atkūrimo (1990) atsiradusią Šv. Valentino šventę. Knygoje skelbiamas klausimynas „Šv. Valentino diena“ $[26,128]$, autoriaus sudarytas siekiant surinkti empirinę medžiagą asmeniniams tyrimams. Dažnai medžiagos rinkimo priemonès būdavo sukuriamos kryptingai renkant empirinę medžiagą konkrečiam tyrimui, todèl jų temos iš dalies atspindi ir etnologinių tyrimų kryptis, tyrejų mokslinius interesus.

Nors J. Mardosos išleistoje knygoje „Apie metodiką ir metodinès priemonès“ tik trys klausimynai tiesiogiai skirti etnografinei medžiagai apie kalendorines šventes rinkti, tačiau pavienių klausimų apie tam tikrus kalendorinių švenčių faktus galime rasti klausimynuose, iš pirmo žvilgsnio visiškai nesusijusiuose su šventemis, pavyzdžiui, „Veido grožis, higiena ir kosmetika“, „Plaukų priežiūra“ (A. Venskienè), „Kolūkis ir kolūkiečiai“ (A. Stanikaitè) ir kt. Ž. Šaknio sudarytame klausimyne „Jaunimo tradicinio socialinio gyvenimo formos ir kaita $\mathrm{XX}$ a. II puseje“ yra atskiras skyrius „Kalendoriniai papročiai“, kuriame rasime klausimų apie jaunimo elgesị, pasilinksminimus ịvairių kalendorinių švenčių metu. Apie atskiras kalendorines šventes galima rasti klausimų tuose klausimynuose, anketose, kurie per tikejjimą, papročius, mitybą, ūkinę veiklą, socialinę elgseną ar kaip nors kitaip siejasi su kalendorinèmis šventèmis.

Tris etnografinių klausimų rinkinius yra parengusi R. I. Merkienė [11, 25, 44]. Pirmuose dviejuose publikuojami tik Istorijos instituto tuometinio Etnografijos skyriaus darbuotoju

(11) [10] Vèliau ši anketa pakartotinai išspausdinta leidinyje Šiokiadieniu ir šventadieniu etnografija [44, 130]. 
klausimynai. Daugiausia jų sukūrusi pati leidinių sudarytoja R. I. Merkienè. 1989 m. išleistame rinkinyje yra 17 klausimynų, iš kurių du susiję su kalendorinėmis šventėmis: „Tautinès šventès ir ižymios datos“ (Ž. Šaknys) bei „Žiemos švenčių persirengèliai“ (A. Vaicekauskas) [24, 21-27]. Ž. Šaknio sudarytas klausimynas skirtas medžiagai apie Lietuvos valstybines šventes - Vasario 16 d., Tautos šventę (rugsejjo 8 d.) ir kt. bei lietuvių tapatumui svarbias gedulingas datas, pavyzdžiui, S. Dariaus ir S. Girèno žūties dieną ir pan., rinkti. Pagrindinis dèmesys sutelktas ị tautinių švenčių šventimą 1918-1940 m., tačiau yra keletas klausimų, kuriais siekiama išsiaiškinti šių švenčių šventimo pabaigą bei tradicijos atgimimą XX a. 9-ajame dešimtmetyje. Keli klausimai skirti lietuvių santykiui su sovietinėmis šventėmis atskleisti. Iki Atgimimo Lietuvoje tokio turinio klausimynų negalèjo būti, todèl etnografinè medžiaga, susijusi su šalies valstybingumu sovietmečiu, oficialiai nebuvo renkama.

Klausimynas „Žiemos švenčių persirengèliai“ sudarytas siekiant surinkti išsamių etnografinių duomenų apie persirengèlių vaikščiojimo laiką, grupės dydị, kaukes, persirengèlių ir juos sutinkančių šeimininkų elgesị ir kt. Klausimai yra orientuoti ị giluminį objekto pažinimą, rodo gerą autoriaus persirengèlių tradicijos išmanymą. Klausimynas turi 21 numeruotą klausimą, tačiau realiai jų yra ženkliai daugiau, nes vienam numeriui dažniausiai priskiriami keli klausimai. Šis klausimynas susijęs su autoriaus tuo metu vykdytų mokslinių tyrimų tema ir tikslais.

1991 m. etnografinių klausimynų rinkinyje iš 30 klausimynų 15 yra susiję su kalendorinėmis šventėmis [11], tai akivaizdžiai daugiau nei prieš dvejus metus išleistame leidinyje. Beveik visi (išskyrus du - „Kasdieniai ir šventiniai žiemos valgiai“ (R. Merkienė, V. Čiubrinskas) ir „Pavasario, vasaros ir rudens šventès“ (R. Merkienè)) klausimynai, juos pataisius, patikslinus, pakartotinai išspausdinti $2007 \mathrm{~m}$. leidinyje „Šiokiadienių ir šventadienių etnografija“ [44]. Šio leidinio sudarytoja, pratarmès ir etnografinių lauko tyrimų pagrindų autorè yra taip pat I. R. Merkienė [44]. Leidinyje išspausdinta 100 klausimynų, kurių dauguma publikuojami pirmą kartą. Jie suskirstyti ị šešias temines grupes. 12 klausimynų, skirtų su kalendoriniais papročiais susijusiai etnografinei medžiagai rinkti, apjungti teminiu pavadinimu „Religinès šventès ir tikèjimai“. Dar 7 klausimynai, skirti etnografinei medžiagai apie tam tikrus šventès aspektus, apeigas, yra skyriuje „Pamaldumo raiška ir magija“. Jau minètas, pakartotinai išspausdintas klausimynas „Atlaidai“ (S. Gutautas ir Ž. Šaknys) patalpintas skyriuje „Gyvenvietè ir bendruomenë“. Taigi, iš viso analizuojamame leidinyje skelbiama 20 klausimynų apie kalendorines šventes. Reiktų pabrèžti, kad 2007 m. išleistame klausimynų rinkinyje sumažèjo atvejų, kai vienas eilès numeris skiriamas keliems klausimams, todèl numeracija labiau atitinka realų klausimų skaičių. Klausimynų labai ịvairi apimtis - nuo 15 iki 49 klausimų. Skirtingi tyrejjai nurodo labai panašų optimalų klausimų skaičių klausimyne. Pavyzdžiui, I. R. Merkienės manymu, klausimyne turi būti ne daugiau kaip 35 klausimai, nes, esant jų daugiau, pokalbis su pateikèju užtruktų ilgiau nei 2 valandas. Tai nuvargintų pateikẻją ir neleistinai ilgai atitrauktų jị nuo kasdienių darbų. Jei klausimų yra daugiau, siūloma ateiti pas respondentą keletą kartų $[44,29]$. Anot V. C. de Muncko, tipiškas klausimynas neturètų apimti daugiau nei 30-40 klausimų. Autoriaus manymu, atliekant tyrimą „paprastai užtenka dvidešimties klausimų, kad išsiaiškintumète tai, ką norite išsiaiškinti“ " $[7,124]$. Ne visos etnografinès medžiagos rinkimo priemonės Lietuvoje buvo sudaromos turint tikslą atlikti tyrimą, kartais tiesiog norèta užfiksuoti tam tikrus kultūros elementus, faktus siekiant tirti savo kultūrą ir etnografinius aprašus išsaugoti ateities kartoms kaip tautinị paveldą. Tokiu atveju klausimų skaičius labai priklausė nuo sudarytojo žinių - jei sudarytojas gerai išmanė temą, klausimynai būdavo 
gana ilgi, nes stengtasi užfiksuoti kuo daugiau informacijos. Tyrëjų siekį sukaupti kuo daugiau duomenų formavo ir naudota pozityvizmo metodologija $[39,62]$.

I. R. Merkienès sudarytuose etnografinių klausimynų rinkiniuose esančius klausimynus apie kalendorines šventes pagal norimos surinkti informacijos pobūdi galima suskirstyti $\mathfrak{i}$ kelias grupes:

1. Siekiama surinkti išsamius duomenis apie vieną šventę. Prie tokių klausimynų priskirtinas „Pati mėgstamiausia šventë“ (I. R. Merkienė), „Trijų karalių švente““ (R. Kundelytė), „Velykų papročiai“ (T. Būgaitè). Pastarajame klausimyne rasime klausimų ne tik apie pačias Velykas, bet ir apie Didžiąją savaitę bei visą velykinị laikotarpị. Šiuo atveju klausimyno pavadinimas ne visai atspindi jame esančių klausimų pobūdị - jis yra per siauras. Etnografinès medžiagos rinkimas priklauso nuo tyrejo metodinių nuostatų, pasirinkto objekto. Šia prasme i̇domus klausimynas „Pati mėgstamiausia švente“, kuriame suformuluotais klausimais siekiama išsiaiškinti tam tikro amžiaus tarpsnio žmonių individualų švenčių reikšmingumą. Klausiama, kokia šventè respondentui labiausiai patiko jaunystėje ir kodèl, prašoma papasakoti, kaip ji buvo švenčiama, ką jos metu veikė skirtingų amžiaus grupių nariai. Pagal ši klausimyną gali būti surinkta informacija ne tik apie pačias ịvairiausias kalendorines, tačiau ir apie šeimos šventes (kai kam pati mėgstamiausia šventẻ gali būti, pvz., gimtadienis). Fiksuojama ne užrašymo momento, bet i praeitị nukreipta informacija - respondento jaunystès prisiminimai. Jau P. Būtèno programoje [25] matome siekį rinkti kuo senesnę informaciją, jai netgi teikiamas pirmumas, tai laikoma svarbesne informacija už gyvenamojo laikotarpio realijas. Ši tarpukario tradicija tęsiama ir vèliau. Kaip pastebejo V. Savonekaitė, buvo renkama medžiaga ne tiek apie egzistuojančius dalykus, kiek užrašinėjami atsiminimai apie „liaudies tradicijas“ $[39,62]$. Galbūt tokią tyrèjų metodologinę poziciją lèmè vèlyvas etnografinès medžiagos rinkimas Lietuvoje, etnografinių duomenų apie praeitị trūkumas, todèl „Lietuvos etnologai kaip duomenų šaltinị vertino ir įvarius konkretaus laikotarpio prisiminimus, ir gyvenimo aprašymus, šitaip kurdami platesni episteminị kontekstą“ $[5,46]$.

2. Klausimynai, kuriais naudojantis norima surinkti kuo išsamesnius duomenis apie dvi ar daugiau švenčių, sezonines šventes arba išskirtinius laikotarpius. Pavyzdžiui, klausimynai „Advento ir gavėnios papročiai“ (I. R. Merkienè, V. Čiubrinskas), „Pavasario, vasaros ir rudens šventès“ (I. R. Merkienè).

3. Siekiama surinkti etnografinę medžiagą apie konkretų faktą, objektą, paprotị ar pan., susijusi su keletu ar visomis kalendorinėmis šventemis, tam tikro objekto naudojimą skirtingų švenčių apeigų metu. Kaip pavyzdį čia galima paminèti klausimynus „Kalendorinių švenčių trukmë“ (I. R. Merkienè), „Šventinė žaluma“ (I. R. Merkienè), „Žiemos meto būrimai ir tikèjimai“ (I. R. Merkienè, V. Čiubrinskas), „Švęstas Velykų ir Sekminių vanduo“ (I. R. Merkienè), „Kaukès, iškamšos ir ju gamyba“ (I. R. Merkienė, V. Čiubrinskas) ir kt. Pastarajame klausimyne didžiausias demesys skiriamas Užgavėnių kaukèms, tačiau teiraujamasi ir apie kaukių darymą, persirengimą per kitas šventes.

4. Norima surinkti etnografinę medžiagą apie tam tikrą faktą, objektą, paprotị ar pan. konkrečios kalendorinès šventės metu: „Kūčių stalas: padengimas, susėdimas prie stalo“ (E. Smalenskaitè), „Velykiniai margučiai ir jų suvartojimas“ (F. Bučaitė, O. Gajauskaitè), „Šventinti verbų žolynai“ (I. R. Merkienè), „Margučių dažymas ir papročiai“ (I. Sinkevičiūtè), „Augalai Joninių šventeje“ (V. Baltakienè) ir kt.

1991 ir 2007 m. išleistuose I. R. Merkienès sudarytuose etnografinių klausimynų rinkiniuose vyrauja 3 ir 4 tipo klausimynai. Jais siekiama surinkti kuo išsamesnę informaciją apie siaurą, tačiau dažnai esminị, šventės aspektą. Kartais pasirenkamas platų ritualinị lauką 
turintis artefaktas (duona, žvakè, kiaušinis, konkretūs augalai ir t. t.) ir siekiama išsiaiškinti jo apeiginị panaudojimą, kultūrinị ịprasminimą. Šiame kontekste kalendorinès šventès yra tik kaip ritualinių veiksmų atlikimo laikas ir vaidina antraeili vaidmenị.

Klausimynų sudarymo metai leidiniuose nepateikiami, galime remtis tik išleidimo data. Knygos „Šiokiadienių ir šventadienių etnografija“ pratarmèje nurodoma, kad tai „per keletą dešimtmečių parengti <...> metodiniai nurodymai“ $[44,14]$. Iš klausimų formulavimo galime suprasti, kad klausimynai skirti jau bebaigiančioms išnykti tradicinès kultūros realijoms užrašyti. Formuluojant klausimus stengtasi surinkti duomenis apie tradicijų nunykimo laiką, jų kaitą, pavyzdžiui, „Kada Velykas pradejo švęsti trumpiau? Kiek dienų švenčia dabar?“ $[44,237]$. Kartais kaitą stengiamasi atsekti, remiantis skirtingų kartų patirtimi, pavyzdžiui, klausiama, kaip šventè seneliai, tèvai ir kaip švenčia duomenų pateikejjai. Laiko dimensijos akcentavimą klausimynuose galèjo nulemti ir tyrèjų dažnai naudotas istorinis lyginamasis metodas [40,67].

Nykstant tradicinès kultūros elementams dažnai tyrèjas yra labiau informuotas asmuo nei pateikẻjas. Greičiausiai dèl to kai kuriuose klausimynuose, paprastai skliaustuose, parašomi tarsi priminimai ar klausimo sukonkretinimai, pavyzdžiui, „Kokioms šventėms Jūsų tėvų namuose dažydavo kiaušinius (pusiaugavėniui, Velykoms, Atvelykiui - Vaikų velykèlėms, Jurginėms, Sekminėms)?“; „Kodèl per minėtąsias šventes reikia dažyti kiaušinius (kad vištos kiaušinių nemètytų, jų nelestų, kad atsimintume sudaužytą Kristaus kūną ir pan.)?“ $[11,26]$. Interviu pirmiausiai užduodamas pagrindinis klausimas ir užfiksuojama respondentui žinoma informacija, o skliaustuose esantys galimi atsakymo variantai paprastai suformuluojami kaip patikslinantys klausimai, tada, jei respondentas ko nors nepaminèjo, siekiant išsiaiškinti, ar jam tokia informacija žinoma. Pačiam respondentui užrašant atsakymus ị tokius klausimus skliaustuose pateikta informacija gali būti suprasta kaip uždaro pobūdžio klausimai ir klaidinti.

Su vèlyvu etnografinès medžiagos rinkimu, siekiu užfiksuoti kuo senesnių gyvojoje tradicijoje jau neegzistuojančių ar retų kultūrinių realijų, siečiau ir tokị klausimų formulavimą, kai tyrèjas ịvardija paprotị, veiksmą, pasako būrimo būdą ar pan. ir klausia respondento, ar jis taip darè, ar žino, kad kažkas taip būtų daręs. Pavyzdžiui, „Ar pirmą Velykų dieną suaugę žmonės ir seni eidavo pas kaimynus vandeniu ir rankšluosčiu nešini jų prausti ar bent jiems rankų numazgoti?“ [11,9] arba „Ar per Užgavènes važiuodavo merginos rogèse susėdusios ant verpsčių? Gal ant verpsčių nuo kalnelių važinėdavosi vaikai?" [11,35]. Tokiu atveju respondentui belieka patvirtinti, kad jis žino tyrèjo pateiktą informaciją ir galbūt dar gali kažką pridurti iš savo patirties arba prisipažinti, kad yra prasčiau informuotas už tyrèję ir pateiktos informacijos nežino. Čia kyla subjektyvumo grèsmè, nes respondentas gali tiesiog patvirtinti pateiktą informaciją nenorẻdamas pasirodyti neišmanèlis.

Lyginant 1991 ir 2007 m. pakartotinai išspausdintus pataisytus klausimynus akivaizdu, kad dažnai patikslinamas bei susiaurinamas objektas. Pavyzdžiui, klausimynas „Švęstas ir nepaprastas vanduo“ (1991), sukonkretinus objektą, pervadintas „Švęstas Velykų ir Sekminių vanduo“ (2007), taip pat atsisakyta su pavadinime minimomis šventèmis nesusijusių klausimų apie vandenị, todèl klausimynas sutrumpejo. Arba klausimynas „Apeiginė ugnis ir duona“ (1991) pertvarkomas ị du atskirus - „Apeiginė ugnis“ ir „Apeiginè duona“ (2007). Pirmajame apie ugnị daugiausia demesio skiriama velykinei ugniai, Joninių laužams, apeigoms su Grabnyčių žvake ir pan. Stengiamasi gauti kuo daugiau informacijos apie bet kokị ne buitinị ugnies naudojimą per kalendorines šventes, smilkymo apeigas, žmonių požiūrị i ugnị ir pan. Klausimynu "Apeiginè duona“ siekiama išsiaiškinti žmonių 
požiūrị i duoną bei surinkti informaciją apie apeiginị duonos naudojimą ir per kalendorines šventes. Pataisytuose klausimynuose dažnai pasikeičia klausimų skaičius. Klausimynai pailgejja, nes atskirai sunumeruojami anksčiau vieną numerị turèję keli klausimai. Klausimų skaičius keičiasi ir dèl objekto patikslinimo arba atsisakius klausimų apie labai senus švenčių elementus, apie kuriuos jaunesnès kartos respondentai jau nieko nežino.

I. R. Merkienès sudarytuose klausimynu rinkiniuose, kaip ir aukščiau aptartame J. Mardosos leidinyje, klausimų apie tam tikrus kalendorinių švenčių aspektus galima rasti ir savo pavadinimu visiškai su šventėmis nesusijusiuose klausimynuose. Jų tematika labai ivvairi: etiketas, jaunimo papročiai, maistas, skalbimas, būrimai ir pan.

Lietuvai atgavus nepriklausomybę, žymiai padaugèjo kalendorinių švenčių tematika publikuotų medžiagos rinkimo priemonių. Jų galima priskaičiuot arti pusšimčio. Tai rodo didžiuli tyrèjų susidomėjimą šia tema. Sovietmečiu daugelio kalendorinių švenčių šventimas buvo labai suvaržytas ar net draudžiamas, todèl ši dvasinès kultūros sritis labai nukentèjo, ir tyrèjai skubèjo fiksuoti atmintyje ar gyvojoje tradicijoje dar išlikusias kultūros realijas. Daugiau publikuota medžiagos rinkimo priemonių, todèl jos tapo labiau prieinamos visuomenei - išspausdintais etnografiniais klausimynai galejo naudotis jau ne vien ji sudaręs tyrèjas, tačiau ir kraštotyrininkai, studentai bei visi norintys. Remiantis Lietuvos istorijos instituto Bibliotekos rankraštyno Etnologijos skyriaus fondo inventorine knyga, galime teigti, kad dauguma XX a. pabaigoje - XXI a. pradžioje išspausdintų medžiagos rinkimo priemonių buvo naudojamos etnografiniams duomenims rinkti. Inventoriniai įrašai rodo, kad informaciją rinko tiek patys tyrèjai, tiek pagalbininkai - kraštotyrininkai, studentai, moksleiviai (12). Taip pat galime įžvelgti sąsajas tarp etnografinès medžiagos rinkimo priemonių kūrimo ir minèto rankraštyno etnografinių aprašų kalendorinių švenčių tema kiekio. Dauguma (13) Lietuvos istorijos instituto bibliotekos Etnologijos skyriaus fondo rankraštyne sukauptų duomenų apie kalendorines šventes yra iš XX a. 9-10-ojo dešimtmečių, t. y. iš to paties laikotarpio, kaip buvo sudaryta daugiausia etnografinès medžiagos rinkimo priemonių.

\section{IŠVADOS}

Spausdintos teminès medžiagos rinkimo priemonès, skirtos duomenims apie kalendorines šventes rinkti, datuotinos XX a. 3-4-uoju dešimtmečiais. Daugiausia klausimų, skirtų empirinei medžiagai apie kalendorines šventes rinkti, paskelbta P. Būtėno sudarytoje „Lietuvių tautotyros žinių ir senienų rinkimo programoje“ ir J. Balio redaguotame „Tautosakos rinkéjo vadove“. Nors pastarasis leidinys skirtas tautosakinei medžiagai rinkti, tačiau daug jame

(12) Paminėsiu tik keletą iš aptartų klausimynų, kurie dažniausiai minimi inventorinèje knygoje, pagal kuriuos surinkta daugiausia medžiagos. I. R. Merkienès klausimynas „Kalendorinių švenčių trukme். Juo remiantis surinktos medžiagos yra 16-oje bylų (IIES b. 1407, 1738, 1739, 1740, 1737, 1741, $1742,1744,1745,1751,1753,1754,1752,1755,1760,1773)$. Medžiaga daugiausiai surinkta moksleivių. Pagal S. Gutauto ir Ž. Šaknio sudarytą klausimyną „Atlaidai“ surinktos medžiagos yra 14-oje bylu (IIES b. 1389, 1430, 1431, 1433, 1434, 1435, 1436, 1441, 1625, 1883, 2044, 2043, 2140, 2210). Medžiaga taip pat rinkta ne pačių autorių. I. R. Merkienès klausimynas „Pati mègstamiausia šventë“. Juo remiantis surinktos medžiagos yra 12-oje bylų (IIES b. 1736, 1737, 1739, 1740, 1741, 1743, 1744, $1746,1748,1754,1760,2015)$. Dažniausiai pagal šị klausimyną medžiagą rinko moksleiviai. Tai buvo užduotis stojantiems ị Jaunųjų etnologų ir Etnokultūros mokyklą.

(13) Lietuvos istorijos instituto bibliotekos Etnologijos skyriaus fondo rankraštyne yra 234 bylos, kuriose užfiksuoti duomenys apie kalendorines šventes. Iki XX a. 9-ojo dešimtmečio užfiksuotos tik 32 bylos. 
suformuluotų klausimų apima ir etnografinius švenčių momentus, o surinkti empiriniai duomenys gali būti vertingi tiek etnologams, tiek tautosakininkams.

Sovietmečiu priemonès etnografinei medžiagai apie kalendorines šventes rinkti sudarinètos ir spausdintos retai. Dauguma lietuvių tradicinių kalendorinių švenčių susijusios su katalikiškuoju kalendoriumi, todèl tokios medžiagos rinkimas buvo ideologiškai nepriimtinas. Pirmoji sovietmečiu kalendoriniams papročiams skirta publikuota anketa buvo „Žiemos periodo kalendoriniai papročiai“. 1982 m. ją sudarè I. R. Merkienė ir V. Čiubrinskas. Rankraštinių priemonių, skirtų medžiagai apie kalendorines šventes rinkti, būta ir anksčiau. P. Dundulienès liudijimu, 1970-1973 m. ji parengè anketas apie kalendorines ir agrarines apeigas. Archyvuose esanti medžiaga apie kalendorines šventes taip pat liudija buvus informacijos rinkimo priemonių.

Atgimimo laikotarpiu ir Lietuvai atkūrus nepriklausomybę (1900) buvo galima nevaržomai tirti savo tautos praeitị, kultūrinị palikimą. Šiuo metu ženkliai išaugo publikuotų etnografinès medžiagos rinkimo priemonių kalendorinių švenčių tema skaičius. 1989-2007 m. autorei pavyko užfiksuoti 47 publikuotas etnografinès medžiagos rinkimo priemones. Mokslininkus, kraštotyrininkus domino kalendorinių švenčių tema. Jie sudarinejo klausimynus turẻdami tikslą tiek susirinkti etnografinę medžiagą savo vykdomiems tyrimams, tiek etnografinio aprašo pavidalu sukaupti ir išsaugoti informaciją kaip paveldą.

Klausimynus, skirtus etnografinei medžiagai apie kalendorines šventes rinkti, pagal norimos surinkti informacijos pobūdị galima suskirstyti ị šias grupes: 1) klausimynai, kuriais siekiama surinkti išsamius duomenis apie vieną šventę; 2) klausimynai, kuriais naudojantis norima surinkti kuo išsamesnę informaciją apie dvi ar daugiau švenčių, sezonines šventes arba išskirtinius laikotarpius; 3 ) siekiama surinkti etnografinę medžiagą apie konkretų faktą, objektą, paprotị ar pan., susijusį su keletu ar visomis kalendorinèmis šventèmis, tam tikro objekto apeigini naudojimą skirtingų švenčių metu; 4) norima surinkti etnografinę medžiagą apie tam tikrą faktą, objektą, paprotị ar pan. konkrečios kalendorinès šventès metu.

Analizuotoms empirinès medžiagos rinkimo priemonèms būdinga tai, kad jose gausu i praeitį orientuotų klausimų. Stengiamasi užfiksuoti kuo senesnius duomenis, žmonių prisiminimus. Skiriasi XX a. I pusès ir XX a. pabaigos medžiagos rinkimo priemonių klausimų formulavimo metodika. XX a. I pusès priemonèse vartojamos laiko, vietos atžvilgiu neapibrèžtos sąvokos „seniau“, „senovès lietuviai“, klausiama, kaip darè seniau, kaip daro dabar ir pan. XX a. pabaigoje sudarytos medžiagos rinkimo priemonès orientuotos konkrečioje vietovejje gyvenančių ar gyvenusių žmonių šventimo būdams nustatyti bei kiek i̇manoma tiksliau apibrèžti laiką. Laiko intervalui nustatyti dažnai naudojami klausimai apie trijų kartų šventimo tradicijas - kaip šventė seneliai, tėvai ir kaip švenčia duomenų pateikẻjas. Tokią i praeitị nukreiptą etnografinès medžiagos rinkimo praktiką visų pirma siečiau su vèlyvu etnografinès medžiagos rinkimu Lietuvoje, etnografinių duomenų trūkumu ir tik po to su metodinemis tyrimų nuostatomis. Buvo skubama pirmiausia užfiksuoti ne gyvenamojo laikotarpio, o praeities realijas, kurias geriausiai žinojo seni žmonès. Nuogąstauta, kad jiems mirus negrižtamai bus prarasta vertinga informacija.

\section{PADE்KA}

Tyrimą finansavo Lietuvos mokslo taryba (sutarties Nr. VAT-30/2012). 


\section{Literatūra ir šaltiniai}

[1] BALYS, Jonas. Pažinkime lietuviškas Kalèdas. Tautos mokykla, 1934, Nr. 24, p. 467-468.

[2] BERNARD, H. Russell. Research Methods in Anthropology: Qualitative and Quantitative Approaches. AltaMira Press, 2006.

[3] B-is, Peliksas [BUGAILIŠKIS]. Šiaulių kraštotyros draugijos penkmetis (1927-1932 metų darbuotès apžvalga). Šiaulių metraštis, Šiauliai: Titnagas, 1933, Nr. 4, p. 61-86.

[4] BUZAS, J. Rinkime duomenis apie Vilniaus verbas ir jų gamintojus. Kraštotyra. Vilnius: Mintis, 1971, p. 335-336.

[5] ČEPAITIENĖ, Auksuolè. Gyvenimo etnografija: vietos, struktūros ir laikas. Besikeičianti Lietuva XX amžiuje. Vilnius: LII 1-kla, 2013.

[6] ČIUBRINSKAS, Vytis. Sovietmečio iššūkiai Lietuvos etnologijai: disciplina, ideologija ir patriotizmas. Lietuvos etnologija: socialinés antropologijos ir etnologijos studijos, 2001, t. 1(10), p. 99117.

[7] DE MUNCK, Victor C. Kultūros tyrimai: patirtis ir apibendrinimai. Kaunas: Vytauto Didžiojo universitetas, 2008.

[8] DUNDULIENĖ, Pranè. Etnografijos mokslas Vilniaus universitete: skiriama aukštuju mokyklu istorijos, etnografijos ir lituanistikos specialybès studentams. Vilnius: LTSR aukšt. ir spec. vid. mokslo m-ja, 1978.

[9] GIEDRIENE், Regina. Mirusiujų pagerbimo papročiai kapinèse. Anketa, 1975.

[10] GUTAUTAS, Stasys; ŠAKNYS, Žilvytis. Atlaidai. Vilnius: Lietuvos mokslų akademijos Lietuvos istorijos institutas, 1990, Etnografinių klausimų lapas Nr. 135.

[11] Kaimo papročiai ir žinija: etnografinių klausimy rinkinys. Sudarè R. Merkienè. Vilnius: Lietuvos istorijos institutas, 1991.

[12] Kaledų ir N. metų švenčių apeigų anketa. Šiauliai: Sp. „Titnagas“, 1932, Šiaulių „Aušros“ muziejaus Etnografinis archyvas, anketa Nr. 3.

[13] KONČIUS, Ignas. Programa etnografijos medžiagai rinkti. Švietimo darbas, 1923, Nr. 6-7, p. 411-417.

[14] KONČIUS, Ignas. Ūkiškosios tautosakos rinkimo programa. Jaunųų Ükininkų ratelių s-gos leidinys, 1936.

[15] KUDIRKA, Juozas. Jonines. Vilnius: Vizija, 1991.

[16] KUDIRKA, Juozas. Jurginès. Vilnius: Informacijos ir leidybos centras, 1997.

[17] KUDIRKA, Juozas. Kūčių naktis. Vilnius: Lietuvos liaud. kultūros centras ir firma „Vizija“, 1990.

[18] KUDIRKA, Juozas. Kūčių stalas. Vilnius: Lyra, Vyturys, 1989.

[19] KUDIRKA, Juozas. Papročiai ir kaimo kultūra. Kaunas: Lietuvos Respublikos žemès ūkio rūmai. 1996.

[20] KUDIRKA, Juozas. Velykų šventès: etnogr. studijos. Vilnius: Mokslas, 1992.

[21] KUDIRKA, Juozas. Velykų šventes. Vilnius: Mintis, 1990.

[22] LAPINSKIENĖ, Lionė. Petro Butėno „Lietuvių tautotyros žinių ir senienų rinkimo programa“. Liaudies kultūra, 2003, Nr. 1(88), p. 44-53.

[23] Lietuvių kalendoriniai metai: anketų rinkinys. Sudarè J. Šorys. Vilnius: Lietuvos liaudies kultūros centras, 1998.

[24] Lietuvos kaimo papročiai: etnografiniu klausimų rinkinys. Sudarè R. Merkienè. Vilnius: Respublikinė jaunųjų turistų stotis, 1989.

[25] Lietuvių tautotyros žinių ir senienų rinkimo programa. Sudarè P. Butènas. Šiauliai: „Vilties“ dr-jos leidinys, 1925. 
[26] MARDOSA, Jonas. Apie metodika ir metodinès priemonès: medžiaga etnografinei praktikai. Vilnius: Vilniaus pedagoginis universitetas. 2002. p. 36.

[27] MARKUCKYTĖ, Elena; PILKAUSKAS, Donatas. Paneveežio mokytojų seminarija (19191936). Voruta, 2012, Nr. 17(755) [žiūrèta 201401 20]. Prieiga per internetą: <http://www.voruta.lt/ panevezio-mokytoju-seminarija-1919-1936/>.

[28] MERKIENĖ, Regina; ČIUBRINSKAS, Vytis. Žiemos periodo kalendoriniai papročiai. Vilnius: Mokslų akademijos Istorijos institutas. LTSR Istorijos ir etnografijos muziejus, 1982, Etnografinių klausimų lapas Nr. 93.

[29] MILIUS, Vacys. Etnografiniu anketu 1945-1973 metu bibliografija. Vilnius: Lietuvos TSR Mokslų akademijos Istorijos institutas, 1974.

[30] MILIUS, Vacys. Etnografinių anketų 1963-1969 m. bibliografija. Kraš̌totyra. Vilnius: Mintis, 1970, p. 351-355.

[31] MILIUS, Vacys. Etnografiniu anketu 1974-1982 metų bibliografija. Vilnius: Lietuvos TSR paminklų apsaugos ir kraštotyros draugija, 1983.

[32] MILIUS, Vacys. Lietuviu etnografijos bibliografija. Vilnius: LII 1-kla, 2001.

[33] MILIUS, Vacys. Mokslo draugijos ir lietuviu etnografija (XIX a. antroji pusé - XX a. pirmoji pusè). Vilnius: Mokslo ir enciklopedijų leidykla, 1993.

[34] MILIUS, Vacys. Programų ir anketų etnografinei medžiagai rinkti bibliografija. Kraštotyra. Vilnius: Mintis, 1963, p. 133-135.

[35] PAUKŠTYTĖ-ŠAKNIENĖ, Rasa; SAVONIAKAITĖ, Vida; SVIDINSKAITĖ, Danguolè; ŠAKNYS, Žilvytis; ŠIDIŠKIENĖ, Irma. Lietuvos etnologijos šaltinių klasifikacija. Liaudies kultūra, 2005, Nr. 1(100), p. 14-27.

[36] REKAŠIUS, Albinas. Lietuviu kalendorinès šventès. Vilnius: Lietuvos TSR MA Istorijos institutas, Etnografijos skyrius, 1990, Etnografinių klausimų lapas, Nr. 128.

[37] REKAŠIUS, Albinas. Verbų apeigos ir papročiai. Vilnius: Lietuvos TSR MA Istorijos institutas, Etnografijos skyrius, 1989, Etnografinių klausimų lapas, Nr. 127.

[38] SAKALAUSKIENĖ, Margarita. Švenčiu tyrimas ir fiksavimas: metodinès rekomendacijos kraštotyrininkams. Vilnius: Lietuvos TSR paminklų apsaugos ir kraštotyros draugija, 1983.

[39] SAVONIAKAITĖ, Vida. Apie Lietuvos etnologijos istoriją. Lituanistica, 2008, t. 54, Nr. 3(75), p. 59-66.

[40] SAVONIAKAITĖ, Vida. Lietuvos etnografija tarp savos kultūros tyrimų. Lituanistica, 2008, t. 54, Nr. 4(76), p. 61-72.

[41] SKRODENIS, Stasys. Tautosakos rinkimo pagrindai. Vilnius: Lietuvos kraštotyros d-ja, 1989.

[42] ŠABAJEVAITĖ, Lidija. Archeologija ir etnografija Vilniaus Stepono Batoro universitete (1919-1939 m.). Istorija, 1980, t. 20(2), p. 95-107.

[43] ŠAKNYS, Žilvytis. Iniciaciniai ir kalendoriniai jaunimo papročiai. Iš: R. Paukštytė-Šaknienè, V. Savoniakaitė, Ž. Šaknys, I. Šidiškienè. Lietuvos kultūra. Mažosios Lietuvos ir Žemaitijos papročiai. Vilnius: Lietuvos istorijos institutas, 2012, p. 77-135.

[44] Šiokiadieniu ir šventadieniu etnografija. Etnografiniu duomenu rinkimo pagrindai. Sudare I. R. Merkienè. Vilnius: Versmé, 2007.

[45] Tautosakos rinkèjo vadovas. Redagavo J. Balys. Lietuvių tautosakos archyvo leidinys. Kaunas, 1936.

[46] Tautosakos rinkèjo vadovas. Antroji laida. Redagavo J. Balys. Lituanistikos instituto Lietuvių tautosakos archyvo leidinys. Kaunas, 1940.

[47] VYŠNIAUSKAITĖ, Angelè. Nurodymai rinkti medžiagai „Europos etnografiniam atlasui“. Vilnius: Lietuvos TSR MA Istorijos institutas, 1969, Etnografinių klausimų lapas Nr. 12. 
[48] Wskazówki dla zbierających przedmioty dla Muzeum Etnograficznego Uniwersytetu Stefana

Batorego w Wilnie. Wilno: Wydane staraniem Pracowni Etnologicxnej U.S.B., 1926.

ASTA VENSKIENÉ

\section{Tendencies of the development of ethnographic materials collecting on the theme of calendar holidays}

Summary

The object of the research is the aids (programmes, questionnaires) which were designed in the first decade of the 20-21st century in Lithuania in order to collect ethnographic materials about calendar holidays. The aim of the research is to perform a quantitative and qualitative analysis in the changes of published ethnographic materials about calendar holidays. The research is based on the analysis of documents (programmes, questionnaires), as well as on descriptive, comparative and interpretative methodology.

The main sources of the article are the bibliographical index of ethnographic questionnaires published since the 5th decade of the 20th century and individual published aids of ethnographic materials collecting and their collections. Having performed the analysis of the aids of ethnographic materials collecting, it has been observed that the first thematic questionnaires in order to collect the materials about calendar holidays were made in the 4th decade of the 20th century. During the Soviet times the creation of aids of ethnographic materials collecting was unwanted due to the religious origin of numerous holidays. The greatest amount of questionnaires to collect ethnographic materials was designed during 1989-2007, the period of Revival and Independence of Lithuania.

Key words: calendar holidays, aids of ethnograhic materials collecting, programmes, questionnaires 